\title{
Öğretmenlerin Mesleki Değerlere İlişkin Görüşlerinin Belirlenmesi
}

\section{Determining Teachers Opinions about Professional Values}

İshak KOZİKOĞLU, Sorumlu Yazar, Dr. Öğr. Üyesi.

Yüzüncü Yıl Üniversitesi, Eğitim Fakültesi.

Email: ishakkozikoglu@yyu.edu.tr.

ORCID: 0000-0003-3772-4179

Ömer BEKLER, MEB Öğretmen

Email: bekleromer@gmail.com

ORGID: 0000-0003-4728-1914

ISSN: 1303-880X

e-ISSN: 2667-7504

http://ded.dem.org.tr

Geliş/Received: 24.01 .2019

Kabul/Accepted: 04.09.2019

Makale Yayın: 25.12.2019

Makale Türü/Article Type:

Araştırma/Research
Atıf/Citation: Kozikoğlu, İ. \& Bekler, Ö. (2019). Öğretmenlerin mesleki değerlere ilişkin görüşlerinin belirlenmesi. Değerler Eğitimi Dergisi, 17 (38), 171-206. DOI: 10.34234/ ded.517186 
Öz: Bu araştırmanın amacı öğretmenlerin mesleki değerlere sahip olma düzeylerini ve bu değerlere ilişkin görüşlerini belirlemektir. Bu araştırmada karma yöntem desenlerinden açıklayıcı sıralı desen kullanılmıştır. Araştırmanın çalışma grubunu, Türkiye'nin farklı illerinde görev yapmakta olan farklı branşlardan 541 öğretmen oluşturmaktadır. Araştırmada veri toplamak amacıyla 'Mesleki Değerler Ölçeği”" ve "yarı-yapılandırılmış görüşme formu” kullanılmıştır. Araştırmada elde edilen verilerin analizinde betimsel istatistikler, $t$ testi, ANOVA ve betimsel analiz tekniği kullanılmıştır. Araştırmanın sonucunda, öğretmenlerin farkl1l1klara saygı duyma mesleki değerine çok yüksek düzeyde sahip olduklarl; kişisel ve toplumsal sorumluluk, şiddete karşı olma ve işbirliğine açık olma mesleki değerlerine ise yüksek düzeyde sahip oldukları belirlenmiştir. Öğretmenlerle yapılan görüşmelerde de benzer sonuçlara ulaşılmıştır. Kadın öğretmenlerin şiddete karşı olma ve iş birliğine açı olma değerlerine erkeklere oranla daha yüksek düzeyde sahip oldukları sonucuna ulaşılmıştır. Eğitim fakültesi mezunlarının diğer fakülte mezunlarına göre, ilkokul ve lise kademesinde görev yapan öğretmenlerin ortaokul kademesinde görev yapan öğretmenlere göre, 16 yıl ve üzeri mesleki deneyime sahip olanların 1-5 ve 6-10 y1l mesleki deneyime sahip olanlara göre daha fazla kişisel ve toplumsal sorumluluk sahibi olduklarını ve iş birliğine daha açık olduklarını düşündükleri sonucuna ulaşılmıştır.

Anahtar Kelimeler: Mesleki değerler, Farklılıklara saygı duyma, Kişisel ve toplumsal sorumluluk, Şiddete karşı olma, İşbirliğine açık olma.

$\&$

Abstract: The aim of this study is to determine the level of teachers' professional values and their opinions. In this study, exploratory sequential design was used. The study group consists of 541 teachers who work from different branches in different provinces of Turkey. "Professional Values Scale" and "semi-structure d interview form" were used for data collection. Descriptive statistics, t test, ANOVA and descriptive analysis were used for data analysis. As a result of the research, it was concluded that teachers have a very high level of professional value of "respect for differences"; they have high level of professional values that are "personal and social responsibility", "being against violence" and "being open to cooperation". Similar results were reached in interviews with teachers. It was concluded that female teachers have higher levels of being against violence and being open to cooperation than men. It was concluded that faculty of education graduates, the teachers working in primary, high school level and those with professional experience of 16 years and be- 
yond have higher level of personal and social responsibility and are more open to cooperation than those who have 1-5 and 6-10 years professional experience, graduates of other faculties, and who work in secondary school level.

Keywords: Professional values, Respect for differences, Personal and social responsibility, Being against violence, Being open to cooperation.

\section{Giriş}

Öğretmenlik mesleği kutsal bir meslek olarak görülmektedir. Günümüz çağında öğretmenden beklenen sadece öğrenciler için öğrenme faaliyetini sağlamak değil, aynı zamanda öğrencilere bilgi, beceri, tutum ve davranışlarıyla örnek veya rol model olmaktır. Bu durum, öğretmenin bilgi ve becerinin yanı sıra mesleğe ilişkin belirli değerlere sahip olmasını ve bu değerlere uygun hareket etmesini gerektirmektedir.

Günümüz toplumunda insanlar birbirlerine karşı yabancılaşmaya, içine kapanmaya ve gittikçe de bireyselleşmeye başlamıştır (Mehmedoğlu ve Mehmedoğlu, 2006). Her ne kadar bunun en büyük sebebi hızla gelişen bilim ve teknoloji olarak görülse de insanları birbirine bağlayan temel bağların etkisini yitirmesi, yok olmaya yüz tutması bu durumun en önemli sebeplerindendir. Bu bağların zayıflaması ve hatta kaybolması insanların artık birbirlerini umursamamasına, değer vermemesine ve en önemlisi de birbirlerine karşı tahammülsüzlüğüne neden olmaktadır. Bu durum da günümüz toplumunda en büyük sorun olarak göze çarpmaktadır. Bu sorun elbette ki çözümü imkânsız bir sorun olmamakla birlikte, 'İnsanı insan yapan temel nitelikler nelerdir? Bireysel sorumluluğumuzun yanında birbirimize karşı sorumluluklarımız nelerdir? Yaptıklarımızın, yaşadıklarımızın ahlaki boyutu nedir?" (Dilmaç, 2002) gibi soruların yanıtlanması bu sorunların çözümünde büyük önem taşımaktadır. Çünkü sorulacak bu sorular insanlar arasındaki en kuvvetli bağ olan ve toplumu güçlendiren 'değer" kavramını gündeme getirmektedir.

Değer insanların hayata, yaşadığı topluma, bulunduğu konuma ve üstlendiği role bakış açısını, bunun yanında bireysel sorumluluğunu ve farkındalığını ifade eder. Alanyazında değer kavramı yerine yaşam biçimi veya hayat tarzı kavramları da kullanılabilmektedir (Çetin, 2004; Sağnak, 2004). Bu nedenledir ki üzerinde uzlaşılmış tek bir değer tanımından bahsetmek mümkün değildir. Rokeach'a (1973) göre değer, insanların davranışlarına yön veren standartlar iken, Hökelekli (2010) değeri, davranışlarımıza yön veren rehberlik eden inanç 
ve kurallar olarak tanımlamıştır. Bunun yanında Özensel (2003), değerlerin toplumun kültürüne ve inançlarına yön veren en önemli kıstas olduğunu, Yapıcı ve Zengin (2003) ise değeri, paylaşılmış ve genelleştirilmiş tutumlar olarak ifade etmektedir. Sabuncuoğlu ve Tüz (2003) ve Sağnak (2005), değer kavramını insanların içinde bulundukları durumları, fiilleri, ortamları bunun yanında iletişim içinde oldukları diğer insanları değerlendirmede, yargılamada benimsedikleri ölçütler olarak ifade etmektedir. Sezgin (2006) ve Erdem (2007) ise değeri, bir davranış ya da durumu diğerine tercih etme eğilimi, davranışlara kaynaklık eden ve onları yargılamayı sağlayan güçlü bir inanç olarak tanımlamaktadır. Yapılan tanımlamalar ve değer kavramına yüklenen anlamlar dikkate alınarak değeri; bireylerin birbirleriyle ilişkilerini düzenleyen, kişinin eğilimlerini tercihlerini, yönelimlerini, yargılamalarını, eleştirilerini benimseme ve sahiplenmelerini etkileyen, toplum içindeki olay ve durumlara önem atfeden standartlar veya ölçütler bütünü şeklinde tanımlamak mümkündür.

Değer, bireylerin yaşadığ topluma uyum sağlamasını, sosyalleşmesini sağlayan en önemli etkenlerden biridir. Birey, yaşadığı toplumun evrensel dünya görüşünü, duygusal yönelimlerini gelenek-görenek ve kültürünü yaşamının ilk yıllarından itibaren öğrenmeye ve benimsemeye başlamaktadır. Bu öğrenme süreci her öğrenmede olduğu gibi ilk olarak ailede başlayarak (Çelik ve Güven, 2011; Fyffe, Hay ve Palmer, 2004; Halstead ve Taylor, 2000; Sabatier ve Willems, 2005), ardından medya, eğitim kurumları ve sosyal çevre aracıllı̆ıyla bu süreç dinamik bir şekilde devam etmektedir (Çelik ve Güven, 2011; Fyffe, Hay ve Palmer, 2004; Halstead ve Taylor, 2000). Her ne kadar bu öğrenme süreci ailede başlayıp sosyal çevre ve medya aracılığıyla yürüse de bu konuda en önemli görev okullara düşmektedir. Çünkü okul bireyin aile, sosyal çevre ve diğer tüm faktörlerden farklı olarak planl1, programlı, bilinçli bir şekilde bireysel, toplumsal ve bilimsel gelişimini sağlamaktadır. Sözü edilen bu gelişmeyi sağlayan okulun program, öğrenci, veli gibi bileşenleri olsa da en temel bileşenlerden birinin öğretmen olduğu su götürmez bir gerçektir.

Öğretmen, bireyi aileden alıp hayata hazırlayan, bireyin en kritik kararlarında yanında olan, öğretimin yanında verdiği eğitim ile bireyin toplumsallaşmas1nı, toplumunun bireyden beklentisine bireyin bu beklentiyi karşılayarak cevap vermesini sağlayan, ona yol gösteren bir rehberdir. Ayrıca öğretmen, mesleki becerilere sahip çağdaş, entelektüel, iyi alışkanlıklara sahip, toplumsal sorunlara karşı duyarlı olan, empati yeteneği gelişmiş, bilim, sanat ve edebiyata ilgi duyan, iyi bir birey (Açıkgöz, 2003), bunun yanında öğretenden ziyade öğren- 
meyi de öğreten kişidir (Türkoğlu, 1996). Öğretmen, öğretme-öğrenme faaliyeti içerisinde programın gerektirdiği şekilde öğretimin planlanmasını, yürütmesini sağlar, bu doğrultuda öğrencilerin ön bilgi ve hazırbulunuşluklarını, ortamı, araç-gereci, materyalleri değerlendirip düzenlemesini yapar. Bunun yanı sıra, öğrencilerde olumlu bir davranış değişikliği oluşturmak, etkili bir sosyalleşme ve iletişim ortamı hazırlamak için de etkili bir sınıf yönetimi gerekmektedir. Öğretmen de bunu göz önünde bulundurarak olumlu bir sınıf iklimi oluşturmaya çalışır (Karip, 2001). Öğretme-öğrenme süreci içerisinde öğretmenin bir diğer görevi de süreç sonunda bireyin kazanımlarını kontrol edebileceği uygun ölçme teknikleriyle sürecin değerlendirmesini yapmaktır (Demirel, 2007; Özden, 1997; Senemoğlu, 2010). Ayrıca, öğretmen bireyin kritik kararlarında ona danışmanlık yaparak onları yönlendiren, cesaretlendiren bir rehber rolü de üstlenir (Büyükkaragöz, Muşta ve Pilten, 1998). Tüm bunların yanında öğretmenin toplumsal açıdan en önemli sayılabilecek bir diğer görevi veya rolü de kültürel değerlerin doğru bir şekilde bireye aktarılmasını, onların toplumsal değerleri benimsemesini, toplumun kendilerinden beklentilerini bilmelerini ve topluma karşı görevlerinin farkında olmalarını sağlamaktır (Kuran, 2002).

Yukarıda sözü edilen, öğretmenin yapması gereken tüm bu görevleri ve üstlendiği rolleri, bunun yanında yürüttüğü faaliyetleri, etkinlikleri kısacası tüm eylemlerini başarıyla ve etkili bir biçimde yerine getirmesi ideal davranışları sergilemekle mümkün olacaktır. Davranış, eylem, rol ve görevlerdeki bu ideallik ölçütü için de öğretmenlik mesleki değerlerinin işe koşulması şarttır. Bu değerler ise öğretmenin sözü edilen görev ve rollerini yerine getirirken düşünce, duygu ve davranışlarına (kendisini bireye, veliye, okul yönetimine, meslektaşlarına ifade etme, karar verme, tercihte bulunma, sorun çözme, yardım etme, empati kurma vb.) rehberlik eden, bu davranışlara yön veren, tutum ve eğilimlerini belirleyen tüm standart ya da ölçütler olarak ifade edilebilir. Mesleki değerler öğretmenleri düşünce, tutum ve davranışlarda desteklemenin yanında (Everard, 1995), meslekte onaylanmayan veya kabul edilemez olan davranış ya da eylemlerin de belirlenerek bu davranış veya eylemlerin engellenmesini sağlayabilmektedir.

Öğretmenlerin sahip olması gereken mesleki değerler çok geniş bir çerçevede ele alınsa da bu değerlerden 'farklllkklara saygl", "kişisel ve toplumsal sorumluluk", "şiddete karşı olma" ve "işbirliğine açık olma" gibi değerler ön plana çıkmaktadır ve bu araştırmada öğretmenlere ilişkin mesleki değerler bu çerçevede ele alınmıştır. Farklılıklara saygılı olma; öğretmenin meslek 
hayatında öğrencilerde, meslektaşlarında gördüğü farklılıkları (sosyo-ekonomik düzey, cinsiyet, etnik köken, kültür vb.) olumlu kabul ile karşılamasını, bu farklılığı desteklemesini ve farklılığı bir zenginlik olarak görmesini ifade etmektedir (Güven, 2012). Ayrıca, farklıl1klara saygı ön yargıdan arınmayı ve empatik düşünmeyi de beraberinde getirerek kişide de olumlu bir benlik algis1 oluşturabilmektedir. Farklı1ıklara saygılı bir öğretmen meslektaşlarını ve bunun yanında çevresindeki herkesi olduğu gibi kabul eder. Ayrıca olumlu bir sınıf iklimi oluşturarak öğrencilerin birbirine karşı saygılı olduğu, birbirlerini olduğu gibi kabul ettiği bir ortam oluşturarak (Derman Sparks, 2010) yarattığı adaletli ve farklılıklara duyarlı ortamla öğrenme-öğretme sürecine de bu şekilde olumlu katkıda bulunur (Ekmişoğlu, 2007).

Kişisel ve toplumsal sorumluluk; öğretmenin meslek hayatındaki eylemlerinde kendini hem kendine hem de topluma karş1 sorumlu hissederek hep daha iyiyi yapmayı, öğrenciyi, dolayısıyla da toplumu ileri taşıyacak faaliyetlerde bulunmayı, bunu yaparken de sorumluluk bilinciyle hareket etmeyi ifade etmektedir. Bunun yanında sorumluluk sahibi bir öğretmen toplumun beklentilerine ve sorunlarına karşı duyarlıdır (Berkowitz ve Daniels, 1963) ve bu duyarlılığ çerçevesinde maddi çıkarı bir kenara bırakarak manevi doyuruculuğu önemser (Chebat, 1986).

Şiddete karşı olma; öğretmenin meslek hayatında çevresine karşı rol model olduğunun bilinciyle davranışlarını düzenlemesini, bu doğrultuda olumsuz durumlar karşısında fiziksel, duygusal ya da sözlü şiddetten uzak durarak olumlu bir rol model olmasını ifade etmektedir (Ögüdülmüş, 2006). Başka bir deyişle, öğretmenin demokratik bir tutum içerisinde olarak çocuğa zorbalıktan uzak durması olarak görülebilmektedir (Demirtaş 2004; Telatar 2012). Bu doğrultuda şiddete karşı bir öğretmen öğrenme ortamında herhangi bir sorunla karş1laşıtı̆ında şiddet ve zorbalık yerine, bulunduğu ortamı demokratik bir şekilde yöneterek soruna yapıcı çözümler üretir (Demirtaş, 2004).

İşbirliğine açı olma ise öğretmenin meslek hayatında meslektaşlarıyla veya velilerle, ögrencileri ya da kendi mesleki bilgi ve becerisini daha ileriye, daha iyiye götürecek her türlü paylaşıma olumlu bakmasıdır. Öğretmenin özellikle velilerle işbirliği yapması bireyin gelişimini olumlu etkilemektedir. Çünkü veli, aile çocuğun eğitim aldığı ilk yerdir ve bu işbirliği de çocuk için hayati bir önem taşımaktadır (Şişman, 2002). Başka bir deyişle eğitimde öğretmen, öğrenci ve veli verimli bir öğretme-öğrenme süreci için en önemli bileşendir (Çelik, 2005). $\mathrm{Bu}$ nedenledir ki öğretmenin meslektaşlar, veliler, öğrenciler ve diğer eğitim 
paydaşları ile dayanışma içinde olması, onun eğitimde işbirliğine açık olduğunun en önemli göstergelerinden biridir.

\section{Araştırmanın Amacı ve Önemi}

$\mathrm{Bu}$ araştırmanın amacı, öğretmenlerin mesleki değerlere sahip olma düzeyini ve mesleki değerlere ilişkin görüşlerini belirlemektir. Türkiye'de öğretmenler ve değerler üzerine yapılan çalışmalarda, genel olarak öğretmenlerin değer sistemleri ya da sahip olması gereken değerler, öğretmenlerin değer sistemlerine yönelik algıları, değerlere ilişkin görüşleri konularının ele alındığı görülmektedir (Altunay ve Yalçınkaya 2011; Dönmez ve Cömert, 2007; Şahin Fırat, 2010). Öğretmenlerle değerler eğitimiyle ilgili yapılan çalışmalar incelendiğinde ise genel olarak öğretmenlerin programlardaki değerlere, değerler eğitimine, değerlerin öğrencilere kazandırılması ve buna ilişkin görüşlerinin incelendiği görülmektedir (Akbaş, 2004; Akkiprik, 2007; Deveci ve Dal, 2007; Kuş, 2009; Yalar, 2010). Bunun yanı sıra, öğretmenlerin değerlere ilişkin tutumları ve değer tercihlerinin belirlendiği çalışmaların da olduğu görülmektedir (Aşkan, 2010; Çankaya ve Seçkin, 2004; Sarı, 2005). Bu durumda, alanyazında değerler ile ilgili yapılan çalışmalar incelendiğinde, değerlerin "öğretmenlerin plan ve programlarına, öğrencilere, meslektaşlarına karşı davranışlarına, mesleki sorumluluklarını yerine getirirken kendisine rehberlik eden, sınıf içi etkinlik ya da sınıf yönetimini sağlamaya yön veren ölçütler takımı" olarak ele alınmadığı görülmektedir. Başka bir ifade ile çalışmalarda öğretmenlerin, sadece belli değer türü açısından değerlendirildiği görülmektedir. Buna karşın öğretmenlerin sahip olmaları gereken mesleki değerlere sahip olup olmadığı ya da ne düzeyde sahip oldukları bütünsel bir bakış açısıyla değerlendirilmediği görülmektedir. Bu eksiklikten yola çıkılarak bu çalışmada, öğretmenlerin sahip olduğu mesleki değerlerin düzeyinin belirlenmesi ve bu doğrultuda öğretmen görüşleriyle de bütünsel bir değerlendirmenin yapılması amaçlanmıştır. Dolayısıyla, bu çalışmada karma yöntem kullanıldığı için öğretmenlerin mesleki değerlerine ilişkin daha derinlemesine veri sağlaması, hem öğretmenlerin mesleki değerlere sahip olma düzeyini ortaya koyması hem de öğretmenlerin bu değerlere ilişkin kendilerinin ve meslektaşlarının gösterdikleri davranışları ortaya koyması yönüyle ilgili alanyazına katkı sağlayacağı düşünülmektedir. Ayrıca, bu araştırma sonuçları öğretmenlerin sahip oldukları mesleki değerleri ortaya koyması bakımından öğretmenlere yönelik hazırlanacak hizmet içi eğitim programlarında değerler eğitimiyle ilgili ihtiyaç analizi çalışmalarına ışık tutacağı düşünülmektedir. 


\section{Yöntem}

\section{Araştırmanın Modeli}

$\mathrm{Bu}$ araştırmada karma yöntem desenlerinden açıklayıcı sıralı desen kullanılmıştır. Açıklayıcı sıralı desende, öncelikle nicel veriler toplanıp analiz edilir ve daha sonra nitel veriler toplanarak hem nicel veriler desteklenir hem de araştırma problemlerine ilişkin daha derinlemesine veri elde edilir. Bu desende, nicel ve nitel veriler bütünleştirilip birlikte yorumlanır (Creswell, 2014). Bu araştırmada da öncelikle nicel veriler toplanmış olup ardından da nitel veriler elde edilmiştir. Bu şekilde, hem daha kapsamlı hem de birbirini destekleyen verilerle daha geçerli sonuçlara ulaşılan bir araştırma gerçekleştirilmesi amaçlanmıştır. Nitel ve nicel verilerin bütünleştirilmesi, tek bir yöntemin kullanıldığı araştırmalara kıyasla araştırma problemlerinin daha derinlemesine ele alınmasına olanak verdiği için (Creswell, 2014) bu araştırmada karma yöntemin kullanılması tercih edilmiştir.

\section{Çalışma Grubu}

$\mathrm{Bu}$ araştırmanın çalışma grubunu, Türkiye'nin farklı illerinde görev yapmakta olan farklı branşlardan 541 öğretmen oluşturmaktadır. Çalışma grubunun belirlenmesinde kolay ulaşılabilir durum örneklemesi esas alınmıştır. Bu yöntemde, araştırmacı erişilmesi kolay olan grup üzerinde çalışır, bu sayede araştırmaya pratiklik ve hız kazandırır (Yıldırım ve Şimşek, 2013). Bu araştırmada çalışma grubu, kolay ulaşılabilirlik ölçütü göz önünde bulundurularak seçilmiş olup veri toplama esnasında gönüllülük esasına göre hareket edilmiştir. Çalışma grubuna ait kişisel özellikler Tablo 1'de sunulmuştur.

\begin{tabular}{llll}
\hline \multicolumn{2}{l}{ Tablo 1: Araştırmaya Katılan Öğretmenlerin Kişisel Özellikleri } & & \\
\hline Değişken & Kategori & Sayı (N) & Yüzde (\%) \\
\hline \multirow{2}{*}{ Cinsiyet } & Kadın & 155 & 28.7 \\
\cline { 2 - 4 } & Erkek & 386 & 71.3 \\
\hline \multirow{2}{*}{ Okul Kademesi } & İlkokul & 175 & 32.3 \\
\cline { 2 - 4 } & Ortaokul & 204 & 37.7 \\
\cline { 2 - 4 } & Lise & 162 & 29.9 \\
\hline Mesleki Deneyim & $1-5$ yıl & 194 & 35.9 \\
\cline { 2 - 4 } & 6-10 yıl & 109 & 20.1 \\
\cline { 2 - 4 } & $11-15$ yıl & 106 & 19.6 \\
\cline { 2 - 4 } & 16 yıl ve üzeri & 132 & 24.4 \\
\hline Görev Yapılan Bölge & Doğu-Güneydoğu Anadolu Bölgesi & 146 & 27.0 \\
\hline & İç Anadolu Bölgesi & 90 & 16.6 \\
\hline
\end{tabular}




\begin{tabular}{lll}
\hline Akdeniz-Karadeniz Bölgesi & 93 & 17.2 \\
\hline Marmara Bölgesi & 123 & 22.7 \\
\hline Ege Bölgesi & 89 & 16.5 \\
\hline
\end{tabular}

Tablo 1'de görüldüğü üzere, araştırmaya katılan öğretmenlerin 155'i (\%28.7) kadın, 386'sı (\%71.3) ise erkektir. Katılımcıların 175'i (\%32.3) ilkokul, 204'ü (\%37.7) ortaokul, 162'si (\%29.9) ise lisede görev yapmaktadırlar. Katılımcıların 194'ü (\%35.9) 1-5 y11, 109’u (\%20.1) 6-10 y1l, 106’s1 (\%19.6) 11-15 yıl, 132 'si $(\% 24,4)$ ise 16 yıl ve üzeri mesleki deneyime sahiptir. Katılımciların 146’s1 (\%27.0) Doğu-Güneydoğu Anadolu Bölgesi'nde, 90’1 (\%16.6) İç Anadolu Bölgesi’nde, 93'ü (\%17.2) Akdeniz-Karadeniz Bölgesi’nde, 123'ü (\%22,7) Marmara Bölgesi’nde ve 89’u (\%16.5) ise Ege Bölgesi’nde görev yapmaktadır.

Ayrıca, araştırmada nitel verileri elde etmek amacıyla 21 öğretmen ile görüşmeler yapılmıştır. Görüşme yapılacak öğretmenlerin belirlenmesinde, amaçlı örnekleme yöntemlerinden maksimum çeşitlilik örnekleme yöntemi kullanılmıştır. Bu yöntemde, araştırmacının amacına en iyi hizmet edecek şekilde, çalışma grubundaki birey ya da durumlar arasından kendi içinde benzeşik farklı durumlar ya da bireyler seçilmektedir (Patton, 2002). Bu araştırmada, görüşme yapılacak öğretmenler belirlenirken yaş, cinsiyet, mesleki kıdem ve görev yap1lan bölge gibi değişkenler dikkate alınarak çeşitlilik sağlanması amaçlanmıştır. Görüşme yapılan öğretmenlerin 11'i kadın, 10'u erkektir. Bu öğretmenlerin 5'i 18-24, 9'u 25-29, 7'si de 30 ve üzeri yaş aralığındadır. Öğretmenlerin 8'i 1-5 y1l, 8'i 6-10 yıl ve 5'i ise 11 y1l ve üzeri mesleki deneyime sahiptir. Ayrıca, görüşme yapılacak öğretmenler her bölgeden 3 öğretmen olacak şekilde eşit sayıda belirlenmiştir.

\section{Veri Toplama Araçları ve Verilerin Toplanması}

$\mathrm{Bu}$ araştırmada kullanılan veri toplama araçlarıyla ilgili bilgiler aşağıda verilmiştir.

Mesleki değerler ölçeği: Tunca ve Sağlam (2013) tarafından geliştirilen, 24 maddeden ve "Beni hiç yansıtmıyor" ile "'Beni çok yansıtıyor" uçları arasında değişen 5'li Likert tipi ölçek, "farklılıklara sayg1 duyma", "'kişisel ve toplumsal sorumluluk", "şiddete karşı olma" ve "'işbirliğine açık olma" olmak üzere dört alt boyuttan oluşmaktadır. Ölçeğin alt boyutlarının Cronbach Alpha iç tutarlılık katsayıları sırasıyla .77, .78, .70 ve .72 olarak hesaplanmış, bu çalışmada ise sırasıyla .72, .79, .74 ve .85 olarak hesaplanmıştır. Bu değerlere göre ölçekten elde edilen verilerin güvenilir olduğu söylenebilir (Büyüköztürk, 2016). Ölçekte; ' 'Arkadaşlarını herhangi bir nedenden (anti sosyal olma, fizik- 
sel özellikleri vb.) dolayı dışlayan öğrencileri uyarırım.”, '’Huzur evi, çocuk esirgeme kurumu vb. sosyal hizmet kurumlarını belli aralıklarla ziyaret etmeye özen gösteririm.", ' 'Okulda engelleri nedeniyle haksızlığa uğrayan öğrencilerin haklarını savunurum.”, 'ÖŎretimi engelleyen (yanındakiyle konuşma, sınıfta dolaşma vb.) öğrencilere gerektiğinde bağırırım.” gibi maddeler yer almaktadır.

Yarı-yapılandırılmış görüşme formu: Araştırmacılar tarafından hazırlanan görüşme formu, 8 sorudan oluşmaktadır. Bu sorular; "'farklılıklara saygı duyma", "kişisel ve toplumsal sorumluluk", "ş̧iddete karşı olma" ve "işbirliğine açık olma" boyutları çerçevesinde hazırlanmıştır. Görüşme sorularının açık ve anlaşılır olmasına özen gösterilmiştir. Hazırlanan görüşme formu, alan uzmanlarının görüşleri doğrultusunda düzenlenerek son hali verilmiştir.

Araştırmada, nicel veriler çevrimiçi veri toplama tekniklerinden günümüzde en çok kullanılanlardan olan Google Form aracılığıyla toplanmıştır. Google Form üzerine aktarılan kişisel bilgi formu ve ölçek bağlantı linki oluşturularak sosyal ağlar, forumlar, e-mail, whatsapp aracılı̆̆ ile paylaşılmış ve çevrimiçi ölçek yaklaşık 5 hafta yayında kalmıştır. Veriler çevrimiçi olarak toplanmıştır. Çevrimiçi olarak veriler toplanırken tamamen gönüllülük esasına göre hareket edildiği için verilerin daha güvenilir olduğu düşünülmektedir. Ayrıca, görüşme yapılan öğretmenlerden Van ilinde görev yapanlarla yüz yüze, farklı il ve bölgelerde görev yapan öğretmenlerle de telefonla görüşmeler yapılarak bu görüşmeler görüşmecinin de izni dâhilinde kayıt altına alınmıştır.

\section{Verilerin Analizi}

Araştırmada, öğretmenlerin mesleki değerlerine yönelik ölçek puanlarının aritmetik ortalamaları ve standart sapmaları hesaplanmıştır. Bu değerler; "1-1.79 arası" çok düşük, "1.80-2.59 arası" düşük, "2.60-3.39 arası" orta, "3.40-4.19 arası" yüksek ve "4.20-5.00 arası" ise çok yüksek düzey olarak yorumlanmıştır (Büyüköztürk, 2016). Öğretmenlerin mesleki değerlere sahip olma düzeylerinin cinsiyet ve mezun olunan fakülteye göre farklılaşıp farklılaşmadığını belirlemek için $t$ testi, okul kademesi ve mesleki deneyime göre farklılaşıp farklılaşmadığını belirlemek için ise ANOVA kullanılmıştır. Araştırmada nitel verilerin analizi için betimsel analiz tekniği kullanılmıştır. Betimsel analiz; tematik çerçeve oluşturma, temalara göre verileri işleme, verilerin tanımlanması ve yorumlanması şeklinde dört aşamadan oluşmaktadır (Yıldırım ve Şimşek, 2013). Bu çalışmada da belirtilen aşamalara uygun hareket edilmiş ve veriler betimlenerek sunulmuştur. Görüşme yapılan öğretmenlere birer kod numarası (Ö1, Ö2, Ö3...) verilmiş, öğretmen görüşlerinden doğrudan alıntılar yapılarak öğretmen 
görüşleri daha açık ve net bir şekilde aktarılmaya çalışılmıştır. Araştırmada güvenirliği sağlamak için; katılımcılar ve araştırmacının konumuna ilişkin ayrıntılı açıklamalar yapılmış, araştırma verileri araştırmacılar tarafından tarafından ayrı ayrı kodlanmış, Miles ve Huberman (1994) tarafından ortaya atılan formül (Güvenirlik=Görüş birliği//[görüş birliği + görü̧s ayrllı̆̆l]) kullanılarak kodlay1cılar arası uyuşum yüzdesi hesaplanmış ve bu değer \% 90 olarak bulunmuştur. Dolayısıyla, kodlamaların yeterli düzeyde güvenilir olduğu sonucuna ulaşılmıştır (Miles ve Huberman, 1994). Araştırmada geçerliği sağlamak için ise verilerin bütünlügü sürekli gözden geçirilmiş ve araştırma süreçlerine ilişkin ayrıntılı açıklamalar yapılmıştır.

\section{Araştırmanın Sınırlılıkları}

$\mathrm{Bu}$ araştırma öğretmenlerle ve nicel verilerin toplanmasında çevrimiçi veri toplama tekniğiyle sınırlıdır. Ayrıca, bu araştırma veri toplama aracı olarak ölçek ve görüşme formuyla sınırlıdır.

\section{Bulgular}

\section{Nicel Bulgular}

Araştırmada öğretmenlerin, öğretmen mesleki değerler ölçeğine verdikleri yanitlar üzerinden hesaplanan betimsel istatistikler Tablo 2'de sunulmuştur.

Tablo 2: Öğretmenlerin Sahip Oldukları Mesleki Değerlere İlişkin Hesaplanan Betimsel İstatistikler

\begin{tabular}{lllll}
\hline Ölçek alt boyutları & $\bar{X}$ & ss & Maksimum değer & Minimum değer \\
\hline Farklılıklara saygı duyma & 4.50 & 0.41 & 5.00 & 2.88 \\
Kişisel ve toplumsal sorumluluk & 3.67 & 0.73 & 5.00 & 1.00 \\
Şiddete karşı olma & 3.83 & 0.74 & 5.00 & 1.00 \\
Isşbirliğine açık olma & 3.96 & 0.96 & 5.00 & 1.00 \\
\hline
\end{tabular}

Tablo 2'de görüldüğü üzere, öğretmenlerin farkl11ıklara sayg1 duyma ( $\bar{X}$ =4.50; ss=0.41) mesleki değerine çok yüksek düzeyde sahip oldukları, kişisel ve toplumsal sorumluluk ( $\bar{X}=3.67$; ss $=0.73$ ), şiddete karş1 olma ( $\bar{X}=3.83$; ss $=0.74$ ) ve işbirliğine açık olma ( $\bar{X}=3.96$; ss=0.96) mesleki değerlerine ise yüksek düzeyde sahip oldukları görülmektedir. Ortalamalar incelendiğinde en yüksek ortalamanın farklılıklara saygı duyma, en düşük ortalamanın ise kişisel ve toplumsal sorumluluk boyutunda olduğu görülmektedir. Öğretmenlerin mesleki değerlere sahip olma düzeylerinin cinsiyete göre anlamlı farklılık gösterip göstermediğine yönelik yapılan $\mathrm{t}$ testi sonuçları Tablo 3’te sunulmuştur. 


\begin{tabular}{|c|c|c|c|c|c|c|c|}
\hline Ölçek alt boyutları & Cinsiyet & Sayı & $\bar{X}$ & $\mathbf{s}$ & sd & $\mathbf{t}$ & $\mathbf{p}$ \\
\hline \multirow{2}{*}{ Farklılıklara saygı duyma } & Kadın & 386 & 4.50 & .40 & \multirow{2}{*}{539} & \multirow{2}{*}{-0.71} & \multirow{2}{*}{.478} \\
\hline & Erkek & 155 & 4.48 & .43 & & & \\
\hline \multirow{2}{*}{ Kişisel ve toplumsal sorumluluk } & Kadın & 386 & 3.70 & .71 & \multirow{2}{*}{539} & \multirow{2}{*}{-1.72} & \multirow{2}{*}{.086} \\
\hline & Erkek & 155 & 3.59 & .75 & & & \\
\hline \multirow{2}{*}{ Şiddete karşı olma } & Kadın & 386 & 3.90 & .70 & \multirow{2}{*}{539} & \multirow{2}{*}{$-3.97 *$} & \multirow{2}{*}{.000} \\
\hline & Erkek & 155 & 3.62 & .80 & & & \\
\hline \multirow{2}{*}{ İşbirliğine açık olma } & Kadın & 386 & 4.04 & .93 & \multirow{2}{*}{539} & \multirow{2}{*}{$-2.97 *$} & \multirow{2}{*}{.003} \\
\hline & Erkek & 155 & 3.77 & .00 & & & \\
\hline
\end{tabular}
$* \mathrm{p}<0.05$

Tablo 3 'te görüldüğü üzere, öğretmenlerin farkl1lıklara sayg1 duyma ( ${ }_{(539)}$ $=-0.71, \mathrm{p}>.05)$ ile kişisel ve toplumsal sorumluluk $\left(\mathrm{t}_{(539)}=-1.72, \mathrm{p}>.05\right)$ değerlerine sahip olma düzeyleri cinsiyete göre anlamlı bir fark göstermezken; şiddete karş1 olma $\left(\mathrm{t}_{(539)}=-3.97, \mathrm{p}<.05\right)$ ve işbirliğine açı olma $\left(\mathrm{t}_{(539)}=-2.97\right.$, $\mathrm{p}<.05)$ değerlerine sahip olma düzeyleri cinsiyete göre kadın öğretmenler lehine anlamlı bir farklılık göstermektedir. Öğretmenlerin mesleki değerlere sahip olma düzeylerinin mezun oldukları fakülteye göre farklılaşıp farklılaşmadığını belirlemeye yönelik yapılan t testi sonuçları tablo 4'te sunulmuştur.

\begin{tabular}{llllllll}
\hline Tablo 4: Öğretmenlerin Mesleki Değerlerinin Mezun Olunan Fakülteye Göre t Testi Sonuçları \\
\hline \multirow{2}{*}{ Ölçek alt boyutları } & Mezun olunan fakülte & Sayı & $\bar{X}$ & s & sd & t & p \\
\hline \multirow{2}{*}{ Farklılıklara saygı duyma } & Eğitim Fakültesi & 333 & 4.51 & 0.41 & 39 & 0.85 & .394 \\
& Diğer & 208 & 4.48 & 0.41 & & & \\
\hline \multirow{2}{*}{ Kişisel ve toplumsal sorumluluk } & Eğitim Fakültesi & 333 & 3.73 & 0.71 & 39 & $2.64^{*}$ & .009 \\
& Diğer & 208 & 3.57 & 0.72 & & & \\
\hline \multirow{2}{*}{ Şiddete karşı olma } & Eğitim Fakültesi & 333 & 3.82 & 0.75 & 39 & -0.10 & .919 \\
& Diğer & 208 & 3.83 & 0.73 & & & \\
\hline \multirow{2}{*}{ İşbirliğine açık olma } & Eğitim Fakültesi & 333 & 4.09 & 0.94 & 39 & $4.06 *$ & .000 \\
& Diğer & 208 & 3.76 & 0.94 & & & \\
\hline
\end{tabular}

$* \mathrm{p}<0.05$

Tablo 4'te görüldüğü üzere, öğretmenlerin farklılıklara saygı duyma (t ${ }_{(539)}$ $=0.85, \mathrm{p}>.05)$ ve şiddete karşı olma $\left(\mathrm{t}_{(539)}=-0.10, \mathrm{p}>.05\right)$ değerlerine sahip olma düzeyleri mezun olunan fakülteye göre anlamlı bir farkl1lık göstermezken; kişisel ve toplumsal sorumluluk $\left(\mathrm{t}_{(539)}=2.64, \mathrm{p}<.05\right)$ ile işbirliğine açık olma $\left(\mathrm{t}_{(539)}=4.06, \mathrm{p}<.05\right)$ değerlerine sahip olma düzeyleri mezun olunan fakülteye göre eğitim fakültesi mezunları lehine anlamlı farklılık göstermektedir. Öğretmenlerin mesleki değerlere sahip olma düzeylerinin öğretmenlerin çalıştıkları okul kademesine göre farklılaşıp farklılaşmadığııı belirlemeye yönelik yapılan ANOVA testi sonuçları Tablo 5 'te sunulmuştur. 


\begin{tabular}{|c|c|c|c|c|c|c|c|c|c|c|}
\hline Betimsel İstatistikler & & & & ANOVA Sc & nuçları & & & & & \\
\hline $\begin{array}{ll}\text { Ölçek alt } & \text { Okul } \\
\text { boyutları Kademesi }\end{array}$ & $\mathrm{N} \mathrm{N}$ & $\bar{X}$ & $\mathrm{~S}$ & $\begin{array}{l}\text { Varyans } \\
\text { Kaynağı }\end{array}$ & K.T ${ }^{\text {sd }}$ & & K.O & $\mathrm{F}$ & & $\begin{array}{l}\text { ark } \\
\text { Scheffe) }\end{array}$ \\
\hline $\begin{array}{ll}\text { Farkl1lık- } & \text { İlkokul } \\
\text { lara sayg1 } & \text { Ortaokul } \\
\text { duyma } & \text { Lise } \\
& \end{array}$ & $\begin{array}{l}175 \\
204 \\
162\end{array}$ & $\begin{array}{l}4.58 \\
4.45 \\
4.47\end{array}$ & $\begin{array}{l}.36 \\
.41 \\
.45\end{array}$ & $\begin{array}{l}\text { Gruplar } \\
\text { arası } \\
\text { Gruplar içi } \\
\text { Toplam }\end{array}$ & $\begin{array}{l}1.621 \\
89.754 \\
91.375\end{array}$ & $\begin{array}{l}2 \\
538 \\
540\end{array}$ & $\begin{array}{l}0.811 \\
0.167\end{array}$ & $4.859 *$ & .008 & $\begin{array}{l}1>2 \\
1>3\end{array}$ \\
\hline $\begin{array}{ll}\text { Kişisel ve } & \text { İlkokul } \\
\text { toplumsal } & \text { Ortaokul } \\
\text { sorumlu- } & \text { Lise } \\
\text { luk } & \end{array}$ & $\begin{array}{l}175 \\
204 \\
162\end{array}$ & $\begin{array}{l}3.87 \\
3.48 \\
3.71\end{array}$ & $\begin{array}{l}.63 \\
.80 \\
.65\end{array}$ & $\begin{array}{l}\text { Gruplar } \\
\text { arası } \\
\text { Gruplar içi } \\
\text { Toplam }\end{array}$ & $\begin{array}{l}14.734 \\
269.770 \\
284.504\end{array}$ & 538 & $\begin{array}{l}7.367 \\
0.501\end{array}$ & $14.692 *$ & .000 & $\begin{array}{l}1>2 \\
1>3 \\
3>2\end{array}$ \\
\hline $\begin{array}{ll}\text { Şiddete } & \text { İlkokul } \\
\text { karşı } & \text { Ortaokul } \\
\text { olma } & \text { Lise }\end{array}$ & $\begin{array}{l}175 \\
204 \\
162\end{array}$ & $\begin{array}{l}3.89 \\
3.71 \\
3.91\end{array}$ & $\begin{array}{l}.78 \\
.74 \\
.69\end{array}$ & $\begin{array}{l}\text { Gruplar } \\
\text { arası } \\
\text { Gruplar içi } \\
\text { Toplam }\end{array}$ & $\begin{array}{l}4.598 \\
295.258 \\
299.857 \\
\end{array}$ & $\begin{array}{l}2 \\
538\end{array}$ & $\begin{array}{l}2.299 \\
0.549\end{array}$ & $4.189 *$ & .016 & $\begin{array}{l}1>2 \\
3>2\end{array}$ \\
\hline $\begin{array}{ll}\text { İşbirliği- } & \text { İlkokul } \\
\text { ne açık } & \text { Ortaokul } \\
\text { olma } & \text { Lise }\end{array}$ & $\begin{array}{l}175 \\
204 \\
162\end{array}$ & $\begin{array}{l}4.35 \\
3.78 \\
3.75\end{array}$ & $\begin{array}{l}.77 \\
.99 \\
.96\end{array}$ & $\begin{array}{l}\text { Gruplar } \\
\text { arası } \\
\text { Gruplar içi } \\
\text { Toplam }\end{array}$ & $\begin{array}{l}40.478 \\
453.450 \\
493.927\end{array}$ & 538 & $\begin{array}{l}20.239 \\
0.843\end{array}$ & $24.013 *$ & .000 & $\begin{array}{l}1>2 \\
1>3\end{array}$ \\
\hline
\end{tabular}

*p<0.05, 1- "ilkokul", 2- "Ortaokul", 3- "Lise"

Tablo 5 incelendiğinde, öğretmenlerin farklılıklara saygı duyma $\left(\mathrm{F}_{(2,538)}\right.$ $=4.859, \mathrm{p}<.05)$, şiddete karşı olma $\left(\mathrm{F}_{(2,538)}=4.189, \mathrm{p}<.05\right)$, kişisel ve toplumsal sorumluluk $\left(\mathrm{F}_{(2,538)}=14.692, \mathrm{p}<.05\right)$ ile işbirliğine açık olma $\left(\mathrm{F}_{(2,538)}=24.013\right.$, $\mathrm{p}<.05)$ değerlerine sahip olma düzeylerinin okul kademesine göre anlamlı bir farkl1lık gösterdiği görülmektedir. Farklılaşan ortalamaların hangi gruplardan kaynaklandığını belirlemek amacıyla yapılan çoklu karşılaştırma testlerinden Scheffe testi sonucunda; kişisel ve toplumsal sorumluluk ile şiddete karşı olma alt boyutlarında lise kademesinde görev yapan öğretmenler ile ortaokul kademesinde görev yapan öğretmenler arasında lise kademesi lehine anlamlı bir farklılık olduğu; farklılıklara saygı duyma, kişisel ve toplumsal sorumluluk ile işbirliğine açık olma alt boyutlarında ise ilkokul kademesinde görev yapan öğretmenler ile ortaokul ve lise kademelerinde görev yapan öğretmenler arasında ilkokul kademesi lehine anlamlı bir fark olduğu belirlenmiştir.

Öğretmenlerin mesleki değerlere sahip olma düzeylerinin mesleki deneyime göre farklılaşıp farklılaşmadığını belirlemeye yönelik yapılan ANOVA testi sonuçları tablo 6'da sunulmuştur. 


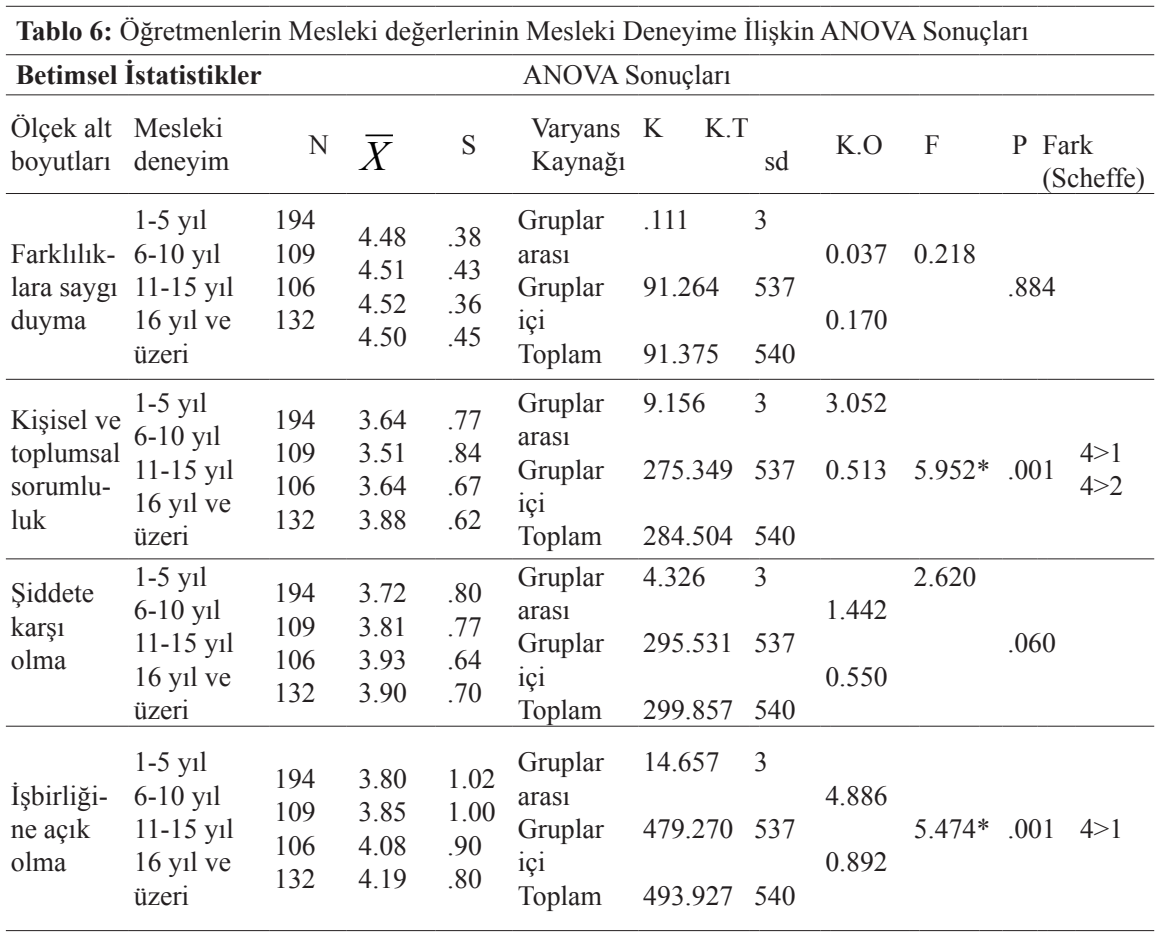

*p<0.05, 1- "1-5 yll”, 2- "6-10 yll”, 3- "11-15 yll”, 4- "16 yll ve üzeri”"

Tablo 6 incelendiğinde, öğretmenlerin farklılıklara saygı duyma $\left(\mathrm{F}_{(3,537)}\right.$ $=0.218, \mathrm{p}>.05)$ ve şiddete karş1 olma $\left(\mathrm{F}_{(3,537)}=2.620, \mathrm{p}>.05\right)$ değerlerine sahip olma düzeyleri mesleki deneyime göre anlamlı bir fark göstermezken, kişisel ve toplumsal sorumluluk $\left(\mathrm{F}_{(3,537)}=5.952, \mathrm{p}<.05\right)$ ile işbirliğine açı olma $\left(\mathrm{F}_{(3,}\right.$ $\left.{ }_{537)}=5.474, \mathrm{p}<.05\right)$ değerlerine sahip olma düzeylerinin mesleki deneyime göre anlamlı bir farklılık gösterdiği görülmektedir. Farklılaşan ortalamaların hangi gruplardan kaynaklandığını belirlemek amacıyla yapılan çoklu karşılaştırma testlerinden Scheffe testi sonucunda; kişisel ve toplumsal sorumluluk boyutunda 16 yıl ve üzeri mesleki deneyime sahip olanlar ile 1-5 y1l ve 6-10 y1l aras1 mesleki deneyime sahip olanlar arasında 16 yıl ve üzeri mesleki deneyime sahip olanlar lehine anlamlı bir farklılık olduğu; işbirliğine açık olma boyutunda ise 16 yıl ve üzeri mesleki deneyime sahip olanlar ile 1-5 yıl arası mesleki deneyime sahip olanlar arasında 16 yıl ve üzeri mesleki deneyime sahip olanlar lehine anlamlı bir farklılığın olduğu belirlenmiştir.

\section{Nitel Bulgular}

Öğretmenler ile yapılan görüşmelerden elde edilen veriler sonucunda katılımc1 görüşleri, "Farklılıklara saygı duyma", "Kişisel ve toplumsal sorumluluk", 
"Şiddete karşı olma" ve "İşbirliğine açık olma" olmak üzere dört ana tema altında gruplandırılmıştır. Belirlenen temalara ilişkin açıklamalara ve öğretmen görüşlerine aşağıda yer verilmiştir.

\section{Farklılıklara saygı duyma}

Bu temaya ilişkin öğretmenlere, 'Meslek yaşamınızda farklılıklara karşı saygllı olduğunuzu düşünüyor musunuz? Nedenleri? Ne tür davranışlar sergiliyorsunuz?" ve "Meslektaşlarınızın farklıllklara karşı saygılı olduğunu düşünüyor musunuz? Nedenleri?" soruları yöneltilmiştir. Görüşme yapılan öğretmenlerin tümü, farklılıklara karşı saygılı olduklarını ifade etmişlerdir. Öğretmenlerin çoğu, öğrencilerle ilişkilerde sosyo-ekonomik durum, etnik köken, dil ve bireysel farklardan (engellilik, başarı düzeyi, öğrenme güçlüğü vb.) kaynaklı farklılıkların farkında olarak hareket ettiklerini ifade etmişlerdir. Bazı öğretmenler de öğrencilerin sosyal yaşam tarzı ve siyasi görüşlerinden kaynaklanan farklılıkların farkında olduklarını ifade etmişlerdir. Bu doğrultuda öğretmenler karşılaştıkları farklılıklar karşısında; dil öğrenme ya da dil desteği alarak daha iyi iletişim kurma, farkl1llğı olduğu gibi kabullenme, sevgi ve şefkat gösterme, önemli hissettirme, eşit davranma, seviyesine uygun etkinliklerle başarı duygusunu tattırma, empati kurma, farkl1lıklar konusunda olumlu rol model olma, çocuğu ortak etkinliklere katma gibi davranışlar sergilediklerini ifade etmişlerdir. Ayrıca öğretmenlerin çoğu, meslektaşlarla ilişkilerde bireysel farklar, coğrafi farklılık (memleket), kültür ve etnik köken bakımından farklılıkların farkında olarak hareket ettiklerini ifade etmişlerdir. Bazı öğretmenler de meslektaşlar arasında sosyal yaşam, tecrübe (yaş, mesleki deneyim) ve din bakımından farkl11ıklar bulunduğunu ifade etmişlerdir. Bu doğrultuda tüm öğretmenler, karşılaştıkları farklılıklara karşı olumlu davrandıklarını ve farklılığı olduğu gibi kabul etme yaklaşımını sergilediklerini ifade etmişlerdir. Bu duruma ilişkin öğretmen görüşlerinden ön plana çıkanlara aşağıda yer verilmiştir.

"Farklllıklara karşı saygllı olduğumu düşünüyorum. Çünkü kimse birbirinin aynisı değil. Yetenek, bilgi ya da fiziksel olarak herkes birbirinden farklıdır ve bu farklllık bir nevi zenginliktir. Sinıfimda kaynaştırma öğrencim var benim mesela. Zihinsel olarak diğerlerinden farkll. Geri değil farkl.. Ben bu farkllllğı gözeterek sinıfta dersimi işliyorum. Ben bu farkllliğa göre hareket ettiğim için sinıf da beni model alıp onlar da farklllığına göre davranıyor çocuğa" (Ö19)

"Öğretmenler açısından bakacak olursam da ben yine dediğim gibi farklılı̆̆ dikkate alırım zaten. Mesela benden yaş̧̧a büyük bir meslektaşıma davranışımla 
benimle yaşıt meslektaşıma davranışım aynı olamaz. Aynı şekilde farkl farklı yerlerden gelmiş ve değişik kültürlerde bir sürü ögretmen arkadaşlarımız var. Farklı siyasi görüsste olanlar filan. Ama hiçbiri benim onlarla iletişim kurmama engel değil ki. Ben onlara bu konuda saygı duyarım onlar da bana." (Ö1)

Ayrıca, görüşme yapılan öğretmenler meslektaşlarının büyük çoğunluğunun farklılıklara karşı saygılı olduğunu ifade etmişlerdir. Öğretmenler, meslektaşlarının öğrencilerle ilişkilerde farklılıklar karşısında farklılığı olduğu gibi kabul ettiklerini, öğrencileri desteklediklerini, sabırlı davrandıklarını, sanatsal etkinlikler düzenlediklerini, ortak ve bütünleştirici davranışlar sergilediklerini ifade etmişlerdir. Ayrıca, görüşme yapılan öğretmenler meslektaşlarının birbirleri arasındaki ilişkilerde karşılaştıkları farklılıklar karşısında farklılıkları olduğu gibi kabul etme ve karşılıklı saygı duyma davranışlarını sergilediklerini ifade etmişlerdir. Bu duruma ilişkin öğretmen görüşlerinden bazılarına aşağıda yer verilmiştir.

"Gözlemlediğim kadarıyla meslektaşlarımın farklllıklara karşı çok bir saygısızlığını görmedim. Öğrencileri hiç hor görmediler, hep olumlu baktılar. Veliler de bazen okuma yazma bilmiyorlar, maddiyatları çok kötü, ama arkadaşlar hep olumlu yaklaştılar." (Ö2)

"Meslektaşlarımın bana göre daha sabırlı ve daha saygllı olduğunu düşünüyorum. Onlar daha sabırlı ve çocukların farkllliklarını daha çok gözetiyorlar diyebilirim. Meslektaşlarım sağ olsunlar birbirlerine de bana karşı da saygllılar. Birbirlerine siyasi görüş olsun ya da kültürel olsun herhangi ayrıştırıc cümleler kurduklarını görmedim. Birbirlerini, daha doğrusu herkes birbirini olduğu gibi kabul ediyor. Farklılıklara karşı olumsuz yönde muamele etmiyor." (Ö20)

\section{Kişisel ve toplumsal sorumluluk}

Bu temaya ilişkin öğretmenlere, 'Meslek yaşamınızda kişisel ve toplumsal sorumluluk sahibi olduğunuzu düşünüyor musunuz? Nedenleri? Ne tür davranışlar sergiliyorsunuz? Ne tür etkinliklere katıllyorsunuz?" ve "Meslektaşlarınızın kişisel ve toplumsal sorumluluk sahibi olduğunuzu düşünüyor musunuz? Nedenleri??" soruları yöneltilmiştir. Öğretmenlerin çoğu, kişisel ve toplumsal sorumluluk sahibi olduklarını ifade etmişlerdir. Öğretmenlerin tamamına yakını topluma faydalı ve daha donanımlı bireyler, bir kısmı da iyi insanlar yetiştirme konusunda kendilerini sorumlu hissettiklerini ifade etmişlerdir. Öğretmenlerin çoğu seminerler, destekleyici kurslar ve sanatsal faaliyetlere katılma, kitap 
okuma, bilimsel-teknolojik gelişmeleri takip etme ve bir kısmı da internet ve hizmet içi eğitimler aracılığıyla kişisel ve mesleki gelişim sağladıklarını ifade etmişlerdir. Ayrıca, öğretmenlerin çoğu toplumsal duyarlılık kapsamında sosyal sorumluluk projeleri ve yardım kampanyalarına katıldıklarını, bazıları da organ bağışı yapma, ağaç dikme ve zararlı alışkanlıklarla mücadele çalışmalarına katılma faaliyetlerinde bulunduklarını ifade etmişlerdir. Bu duruma ilişkin öğretmen görüşlerinden birine aşağıda yer verilmiştir.

"Kişisel ve toplumsal sorumluluk sahibi olduğumu düşünüyorum. Öğretmenlik zaten başlı başına sorumluluk gerektiren bir meslek. Topluma iyi bireyler kazandirmak, topluma zarar vermeyecek, insanlara zarar vermeyecek bireyler yetiştirmek de yine benim sorumluluğum. Bunun yanında kendimi gelişstirmek de zorundayım. Mesela mesleğe ilk başladığım yıllarda akıllı tahta filan yoktu, ama artık var. Ben kalkıp da ben başladığımda yoktu deyip kenara çekilemem. Bunun için seminere katıldım ve bu konuda bana faydası oldu. Bunun yanında derslerde etkili olacak, çocuğun daha etkili öğrenmesini sağlayacak destekleyici kurslar alarak kendimi geliştirmeye çalışıyorum. Bunun yanında kitap okuyorum, alanda yapılan çalışmaları elimden geldiğince takip etmeye çalışıyorum.” (Ö6)

Ayrıca, öğretmenlerin çoğu umursamazlık, mesleği isteyerek yapmama, mesleğin ciddiyetinin farkında olmama gibi nedenlerden dolayı özellikle mesleki deneyimi fazla olan meslektaşlarının kişisel ve toplumsal sorumluluk sahibi olmadıklarını düşündüklerini ifade etmişlerdir. Bunun yanı sıra, öğretmenlerin çoğu seminerler ve hizmet içi eğitimlerin faydasız olduğunu düşünmeleri, karş1lığında maddi kazanç olmaması, umursamazlık, çevredeki olumsuz örnekler, her zaman iyi olduğunun düşünülmesi ve öğretmenliğin sadece mesai olarak görülmesi gibi nedenlerden dolayı meslektaşlarının kişisel ve mesleki gelişimleri konusunda herhangi bir çaba harcamadıklarını belirtmişlerdir. Öte yandan, öğretmenlerin çoğu meslektaşlarının toplumsal duyarlılık sahibi olduklarını ifade etmişlerdir. Bu konuda meslektaşlarının yardım kampanyaları düzenleme, organ bağışı yapma, veli eğitimleri düzenleme, yaşlı ve engelli bakım evlerini ziyaret etme gibi faaliyet ve etkinliklere katıldıklarını ifade etmişlerdir. Bu duruma ilişkin öğretmen görüşlerinden bazılarına aşağıda yer verilmiştir.

"Meslektaşlarımdan çok azının mesleki anlamda kişisel ve toplumsal sorumluluk sahibi olduğunu düşünüyorum. Az bir kısmı bence işin ciddiyetindeler. Ama burada yaşça büyük ve emekliliği gelmişs olan öğretmenleri ayıracağım. Çünkü onlar derse girip çıkıp eve gidiyorlar, hepsi bu. Onlar için okul, eğitim mesaiden ibaret." (Ö19) 
"Meslek grubum itibari ile yaşı ilerlemiş sınıf öğretmenlerinin kişisel olarak da toplumsal olarak da duyarlı bir iş icra ettiklerini düşünmüyorum. Yaş olarak daha genç arkadaşların bu gelişimlere daha çok açık olduğunu düşünüyorum. Yine yaş olarak daha genç öğretmenlerin toplumsal ve kişisel sorumluluğu daha çok önemsediğini ama yaşı ilerlemiş öğretmenlerin bu konuya dikkat etmediğini düşünüyorum. Kişisel ve mesleki gelişim açısından da durum böyle. Yaşı ilerlemiş öğretmen arkadaşlarım her şeyi tecrübeyle halledebileceklerini, en iyilerinin zaten kendilerinin olduğunu düşündükleri için kendilerini geliştirme çabası hiçbirinde görmedim." (Ö11)

"Toplumsal duyarlılık noktasında çoğu meslektaşlarımın duyarlı olduğunu düşünüyorum. Sadece öğrencileri ile değil, aynı zamanda veliler ile de yakından ilgilenen ve sorunları ile ilgilenerek onlara eğitimler düzenlemeye çalışan meslektaşlarım mevcut. Yine bunun dışında Kızılay gibi toplum yararına çalışan kurumlara sürekli katkı veren meslektaşlarım da mevcut." (Ö5)

\section{Şiddete karşı olma}

$\mathrm{Bu}$ temaya ilişkin öğretmenlere, "'Meslek yaşamınızda şiddete karşı olduğunuzu düşünüyor musunuz? Nedenleri? Ne tür davranışlar sergiliyorsunuz?” ve '’Meslektaşlarınızın şiddete karşı olduğunuzu düşünüyor musunuz? Nedenleri? "’soruları yöneltilmiştir. Öğretmenlerin tamamına yakını şiddete karşı olduklarını ifade etmişlerdir. Buna sebep olarak da birçok öğretmen şiddetin sorunu çözmemesi, mevcut sorunları daha da büyütmesi olarak göstermişlerdir. Bazı öğretmenler de şiddetin verimi düşürdüğünü, karşılıklı sevgi ve saygıyı bitirdiğini, çocuğu okuldan ve arkadaşlarından soğuttuğunu, öğretmenleri olumsuz rol model olarak gösterdiğini ifade ederek şiddete karşı olduklarını ifade etmişlerdir. Öğretmenlerin çoğunluğu şiddet uygulamak yerine sorunu konuşarak anlamaya, doğru davranışı fark ettirmeye çalıştıklarını, bazıları da değer verme, öğrenciye karşı hassas davranma, sınıftan çıkarma veya öğrenciyi ortamdan uzak tutma, empati, olumlu rol model olma davranışları sergilediklerini ifade etmişlerdir. Bu duruma ilişkin öğretmen görüşlerinden birine aşağıda yer verilmiştir.

"Şiddete tabi ki karşıyım. Sadece meslekte değil, her yerde karşıyım. Şiddet çözüm değil çünkü. Sadece güç göstermedir. Acizliktir. Herhangi bir sorunda şiddet uygularsanız sorunu çözmezsiniz, sadece bastırırsınız. Ama bu defa da çocukta gördüğü şiddetten dolayı tahribat oluşur. Böylece de sorun bir iken iki olur. Yani şiddet sorunu çözmek yerine daha da büyütür. Çocuklarda bir sorun olduğunda şiddet yerine karşıma alıp yaptıkları yanlışı anlatıyorum, doğruyu fark etmele- 
rini sağlıyorum. Sınıf ortamında hiçbir çocuğu yermem, sınıfta küçük düşürücü söz söylemem, kısacası hepsine değer veririm. Sinıf ortamına herhangi bir şiddet unsuru sokmam. Biz ĕgitimciler olarak şiddeti eğitime sokarsak toplumda şiddet nasıl önlenecek ki? Okul örnek olmall, çocuk burada şiddeti değil, şiddetin kötü olduğunu ögrenmeli." (Ö18)

Ayrıca, öğretmenlerin çoğu özelikle meslekte deneyim sahibi olan meslektaşlarının şiddet eğiliminde olduklarını ifade etmişlerdir. Buna sebep olarak da meslektaşlarının ilerlemiş yaşlarından dolayı en küçük şeye bile tahammülsüz olduklarını, duygusal veya psikolojik şiddet gibi şiddet türlerinin ispat edilmesinin zor olduğunu, meslektaşlarının sabırsız olduğunu ve karakter özelliklerinde şiddete yatkınlıklarının olduğunu düşündüklerini ifade etmişlerdir. Öğretmenler meslektaşlarının azarlama, alaycı ifadeler, vurma, baskı, umursamama, aşağılama, hor görme, başarısızlıkla etiketleme gibi şiddet içeren davranışlar sergilediklerini ifade etmişlerdir. Bu duruma ilişkin öğretmen görüşlerinden bazılarına aşağıda yer verilmiştir.

"Meslektaşlarımdan şiddete meyilli olanlar elbette çok var. Fiziksel olarak da duygusal, psikolojik olarak da var. Ancak fiziksel şiddete çok başvurmuyor kimse, çünkü o zaman meslekleri tehlikeye giriyor. Korkuyorlar anlayacă̆ınız. Ne acı değil mi? Ancak fiziksel ya da duygusal şiddet iz birakmadiğ için ya da şiddet uygulandığı belli olmadığı için sürekli başvuruluyor ne yazık ki. Şunu da belirtmek istiyorum genç arkadaşlar eskilerden daha iyi bu konuda yaşlart yakın diye mi bilmiyorum ama arkadaş gibiler. En yaramaz çocukla bile arkadaş gibi oluyorlar. Çocuğun da hoşuna gidiyor bu. Yaşlı hocalarda bu durum hiç yok. Tahammül etmiyorlar genelde. Çocukları aşağılama, azarlama çok fazla oluyor bu hocalarda. Hatta kulak çekme gibi fiziksel boyuta varabiliyor." (Ö6)

\section{İşbirliğine açık olma}

Bu temaya ilişkin öğretmenlere, ' Meslek yaşamınızda işbirliğine açık olduğunuzu düşünüyor musunuz? Nedenleri? Ne tür davranışlar sergiliyorsunuz?’'ve ' 'Meslektaşlarınızın işbirliğine açık olduğunuzu düşünüyor musunuz? Nedenleri? ’” soruları yöneltilmiştir. Öğretmenlerin çoğu; bilgi ve tecrübe eksikliklerini giderme, çocuklara daha faydalı olma, mesleki anlamda ilerleme sağlama, yeni şeyler öğrenme, eğitim niteliği arttırma gibi gerekçelerden dolayı meslektaşlarıyla işbirliğine açık olduklarını ifade etmişlerdir. Öğretmenler, işbirliği konusunda çoğunlukla sorumluluk paylaşma, ortak sınav hazırlama, projeler geliştirme ve yürütme, danışma ve yardımlaşma gibi davranışlar sergilediklerini ifade etmişlerdir. Öte yandan, öğretmenlerin büyük çoğunluğu velilerle işbirliği 
yapmak istediklerini, fakat çoğunlukla velilerin ilgisiz olması veya kalabalık aile yapısından dolayı velinin çocuğu umursamaması yüzünden velilerle işbirliği yapamadıklarını ifade etmişlerdir. Bu duruma ilişkin öğretmen görüşlerinden birine aşağıda yer verilmiştir.

"Işsbirliğine açık olduğumu düşünüyorum tabi ki. Çünkü her şeyi ben bilemem. Bazı konularda diğer arkadaşlarımdan yardım alırım. Mesela sinıf yönetiminde diğer arkadaşlardan yardim isterim. Onların tecrübelerinden faydalanmak isterim. Çünkü birlikte daha güzel şeyler, daha etkili şeyler çıktı̆ını düşünüyorum. İşbirliği konusunda sürekli yaptığımız bir şey de ortak sinavlar hazırlamak. Bu şekilde hem daha kolay oluyor sınavları hazırlamak, hem de farklı bakış açılarıyla daha kaliteli sinavlar ortaya çıkabiliyor ortaya. Velilerle de bir şeyler yapmak istiyorum, ancak veliler ilgisiz olduğu için havada kallyor bu dediklerim. Yine yalnız kalyyorum." (Ö3)

Ayrıca, öğretmenlerin çoğu meslektaşlarının mecburiyetten dolayı işleri paylaşma gereksinimi, ortak proje ve çalışmalar ve bazı sınavların ortak yapılması gerekliliğinden dolayı işbirliği yapmak durumunda kaldıklarını ifade ederken bazı meslektaşlarının ise gönüllü olarak işbirliğine açık olduklarını belirtmişlerdir. Bu doğrultuda öğretmenler, meslektaşlarının işbirliği konusunda sorumluluk paylaşma, yardımlaşma gibi davranışlar sergilediklerini ifade etmişlerdir. Öte yandan, öğretmenlerin çoğu meslektaşlarının velilerle işbirliği noktasında sorun yaşadıklarını ifade etmişler ve meslektaşlarının velilerle muhatap olmak istememelerini, velileri sorun olarak görmelerini, velilerin ilgisizliğini bu durumun sebepleri olarak göstermişlerdir. Bu duruma ilişkin öğretmen görüşlerinden birine aşağıda yer verilmiştir.

"Meslektaşlarımın da işbirliğine açık olduğunu düşünüyorum ama genelde mecbur olunca açık oluyorlar. Öbür türlü kaçıyorlar. Mesela okuldaki tören veya kutlama olaylarında mecbur olmasalar işbirliğine gitmezler ki kaçarlar. Biraz da çıkar ilişkisi sanırım bu durum. Sinavlar da öyle. Ortak sinav yapmak kolaylarına geliyor. Her ders için sinav hazırlamaktansa bir ders için hazırlyyorlar. Bunun yanında gerçekten yardımlaşma ya da diğer meslektaşının tecrübesinden faydalanmak adına işbirliğinde bulunan meslektaşlarım da yok değil. Bazı arkadaşlar da meslektaşla alakadar olmayıp sırf çocuğun menfaatine bir durum olduğu için ortak çalışmalarda yer alabiliyor. Arkadaşlarımın da velilerle işbirliğinde sıkıntı yaşadıklarını söyleyebilirim. Birçoğu veliyi tanımıyor, görmemişler bile. Buna rağmen evine gidip veliyi bulan da var, aman veli ilgilenmiyorsa kendi çocuğuyla ben ne yapayım deyip bırakan da var. Ancak neredeyse tamamı velilerle iletişimi bırakmış durumda." (Ö8) 


\section{Tartışma, Sonuç ve Öneriler}

Öğretmenlerin mesleki değerlere sahip olma düzeyinin ve mesleki değerlere ilişkin görüşlerinin belirlenmesinin amaçlandığı bu araştırmada öğretmenlerin farklılıklara saygı duyma mesleki değerine çok yüksek düzeyde sahip oldukları, kişisel ve toplumsal sorumluluk, şiddete karşı olma ve işbirliğine açık olma mesleki değerlerine ise yüksek düzeyde sahip oldukları sonucuna ulaşılmıştır. Öğretmenlerle yapılan görüşmelerde de benzer sonuçlara ulaşılmıştır. Öğretmenlerle yapılan görüşmelerde de öğretmenlerin tamamı, kendilerinin ve meslektaşlarının farklılıklara karşı saygılı olduklarını; öğretmenlerin tamamına yakınının kendilerinin ve meslektaşlarının şiddete karşı olduklarını, işbirliğine açık olduklarını ve kişisel/toplumsal sorumluluk sahibi olduklarını düşündükleri sonucuna ulaşılmıştır. Görüşmelerden elde edilen bu sonuçlar nicel verilerle örtüşür ve bu sonuçları destekler niteliktedir. Alanyazında yapılan çalışmalara bakıldığında, bu araştırma sonucunu destekler nitelikte sonuçlara ulaşıldığ1 görülmektedir. Tunca (2012), Yurtseven (2003), Çoban, Karaman ve Doğan (2010) ve Altınkurt ve Yılmaz'ın (2011) yaptıkları çalışmalarda bu araştırma sonuçlarına paralel olarak öğretmenlerin en yüksek düzeyde sahip oldukları mesleki değerin "farklılıklara saygı" olduğu sonucuna ulaşmışlardır. Buna ek olarak, Akın ve Özdemir (2009) ve Yazıcı (2011) yaptıkları çalışmalarda, öğretmenlerin yüksek düzeyde demokratik değerlere sahip oldukları sonucuna ulaşmışlardır. Bu sonuç da araştırma sonuçlarıyla benzer nitelik taşımaktadır. Bunun yanı sıra bu araştırmada, öğretmenlerin "şiddete karşı olma" mesleki değerine yüksek düzeyde sahip olduğunu düşünmesine karşın alanyazında yap1lan çalışmalar incelendiğinde (Gözütok, 2008; Hatunoğlu ve Hatunoğlu, 2005; Tunca, 2012) ulaşılan sonuçların bu araştırmadakini destekler nitelikte olmadığ 1 görülmektedir.

Öğretmenlerle yapılan görüşmelerde öğretmenlerin öğrencilerde karşılaştıkları farklılıklar karşısında; dil öğrenme ya da dil desteği alarak daha iyi iletişim kurma, farklılığı olduğu gibi kabullenme, sevgi ve şefkat gösterme, önemli hissettirme, eşit davranma, seviyesine uygun etkinliklerle başarı duygusunu tattırma, empati kurma, farklılıklar konusunda olumlu rol model olma, çocu$\breve{g u}$ ortak etkinliklere katma gibi davranışlar sergilediklerini ifade etmişlerdir. Bunun yanında öğretmenler meslektaşları arasındaki farklılıkları da olduğu gibi kabul etme, empati davranışları sergileyerek karşıladıklarını belirtmişlerdir. Bu sonuçlara bakıldığında öğretmenlerin farklılıklar karşısında her zaman olumlu davranışlar sergileyerek farklılıkları hoş karşıladıklarını, bu farklılıkları ileti- 
şimde engel olarak görmediklerini söylemek mümkün olacaktır. Öğretmenlerin çoğunun kişisel ve toplumsal sorumluluk sahibi olduklarını düşündükleri, topluma faydalı ve daha donanımlı bireyler, iyi insanlar yetiştirme konusunda kendilerini sorumlu hissettikleri belirlenmiştir. Öğretmenlerin çoğunun şiddet uygulamak yerine sorunu konuşarak anlamaya, doğru davranışı fark ettirmeye çalıştıkları, bazıları da değer verme, öğrenciye karşı hassas davranma, sınıftan çıkarma veya öğrenciyi ortamdan uzak tutma, empati, olumlu rol model olma davranışları sergiledikleri belirlenmiştir. Ayrıca, öğretmenlerin işbirliği konusunda çoğunlukla sorumluluk paylaşma, ortak sınav hazırlama, projeler geliştirme ve yürütme, danışma ve yardımlaşma gibi davranışlar sergiledikleri belirlenmiş̧ir. Bu sonuçlardan hareketle, öğretmenlerin farklılıklara saygı duyma, kişisel ve toplumsal sorumluluk, şiddete karşı olma ve işbirliğine açık olma mesleki değerlerine yüksek düzeyde sahip olduklarını düşündüklerini söylemek mümkündür. Bunun yanı sıra öğretmenlerin bu davranışlara sahip olmasıyla öğretme-öğrenme sürecini olumlu sürdürdüklerini, iyi bir rol model olduklarını, kişisel sorumluluklarını yerine getirip meslektaşlar arası yardımlaşmalarda da bulunarak öğrenmeyi desteklediklerini söylemek mümkündür.

Araştırma sonucunda öğretmenlerin farklılıklara saygı duyma ile kişisel ve toplumsal sorumluluk değerlerine sahip olma düzeylerinin cinsiyete göre anlamlı bir fark göstermediği, buna karşın kadın öğretmenlerin erkek öğretmenlere kıyasla şiddete karşı olma ve işbirliğine açık olma değerlerine daha yüksek düzeyde sahip oldukları sonucuna ulaşılmıştır. Öğretmenlerle yapılan görüşmelerde de erkek öğretmenler kadın öğretmenlerin daha sabırlı olduğunu, sorunlara karşı daha olumlu ve 1lımlı yaklaştığını ifade ettikleri görülmektedir. Bu araştırma sonucuna paralel olarak, Büyükkaragöz ve Kesici (1996), Akın ve Özdemir (2009) yaptıkları çalışmalarda, işbirliği ve dayanışma boyutunda kadınlar lehine anlamlı bir fark bulmuşlardır. Bu araştırmadan farklı olarak Bilge (1997), Yöndem ve Bıçak (2008) yaptıkları çalışmalarda, kadın ve erkek öğretmenlerin öfke, ceza ve şiddet tutumlarının benzer olduğu sonucuna ulaşmışlardır. Benzer şekilde, Karadağ, Baloğlu ve Yalçınkayalar (2006), Yazıcı (2011), Oğuz (2011) ve Yılmaz (2011) öğretmenlerin demokratik değerlerini inceledikleri çalışmalarında, kadın ve erkek öğretmenlerin benzer değerlere sahip olduğu sonucuna ulaşmışlardır. Bu durumda, cinsiyete göre çalışmalarda farklı sonuçlara ulaşıldığg görülmektedir. Bu araştırmadan elde edilen sonuçlar değerlendirildiğinde, "farklılıklara saygı duyma" ve "kişisel ve mesleki sorumluluk" mesleki değerlerinde kadın ve erkek öğretmenlerin benzer özellikler gösterdikleri; buna karşın kadın öğretmenlerin erkek öğretmenlere göre daha 
az şiddete başvurdukları ve işbirliğine daha açı oldukları söylenebilir. Kadın öğretmenlerin anaç ruhlu olmalarının şiddete daha az yönelmelerini sağladığ 1 söylenebilir. Kadın öğretmenlerin erkeklere oranla iletişime daha açık olmaları ve sosyal becerilerinin daha gelişmiş olması işbirliğine daha istekli olmaları üzerinde etkili olduğu düşünülebilir.

Araştırma sonucunda, öğretmenlerin farklılıklara saygı duyma ve şiddete karŞ1 olma değerlerine sahip olma düzeylerinin mezun olunan fakülteye göre anlamlı bir farklı1ık göstermediği; buna karşın eğitim fakültesi mezunlarının diğer fakülte mezunlarına göre kişisel ve toplumsal sorumluluk ile işbirliğine açık olma değerlerine daha yüksek düzeyde sahip oldukları sonucuna ulaşılmıştır. Bu araştırma sonuçlarına paralel olarak, Tunca (2012) yaptığı çalışmada, öğretmenlerin sahip olduğu mesleki değerlerden farklılıklara saygı duyma ve şiddete karşı olma mesleki değerlerinin mezun olunan fakülteye göre anlamlı bir fakl1lık göstermediği, buna karşın kişisel ve toplumsal sorumluluk ile işbirliğine açık olma mesleki değerlerinin mezun olunan fakülteye göre eğitim fakültesi mezunları lehine anlamlı farklılığın olduğu sonucuna ulaşmıştır. Bu sonuçlardan hareketle, öğretmenlerin mezun oldukları fakülte fark etmeksizin farklılıklara saygı duyma ve şiddete karşı olma mesleki değerlerinin benzer düzeyde olduğu, buna karşın eğitim fakültesi mezunlarının diğer fakülte mezunlarına göre kişisel ve toplumsal gelişim anlamında kendilerini daha sorumlu hissettiklerini ve işbirliğine daha açık olduklarını söylemek mümkündür. Eğitim fakültelerinde öğretmen adaylarının öğretmenlik bilinciyle yetiştirilmesinin, bu mesleğin gerektirdiği sosyal, bireysel becerilerle donatılmasının elde edilen bu sonuçta etkili olduğu söylenebilir. Bunun yanı sıra, öğretmen adaylarının fakültede gördükleri "topluma hizmet uygulamaları" gibi dersler ile yapılan grup çalışmaları, topluma hizmet faaliyetleri sayesinde sosyal olarak gelişmelerinin de bu sonuca ulaşmada etkili olduğu söylenebilir.

Araştırma sonucunda, ilkokul ve lise kademesinde görev yapan öğretmenlerin ortaokul kademesinde görev yapan öğretmenlere göre daha fazla kişisel ve toplumsal sorumluluk sahibi olduklarını düşündükleri ve şiddete daha karşı oldukları, ilkokul kademesinde görev yapan öğretmenlerin lise ve ortaokul kademesinde görev yapan öğretmenlere göre farklılıklara karşı daha saygılı olduklarını ve işbirliğine daha açık olduklarını düşündükleri belirlenmiştir. Alanyazın incelendiğinde, öğretmenlerin mesleki değerlerinin okul kademesine göre incelendiği bir araştırmaya ulaşılmamıştır. Bu araştırma sonuçlarından hareketle, ilkokul kademesinde görev yapan öğretmenlerin daha fazla kişisel ve toplumsal 
sorumluluk hissetmelerinin ve şiddete daha fazla karşı olmalarının nedeni olarak ilkokul öğrencisinin kendi kararlarını veremeyecek düzeyde olması, yaşlarının küçük olması ve bunun için de öğretmenin daha fazla rehberliğine ihtiyaç duymasından dolayı öğretmenin bu sorumluluğu üstlenmesi ve aynı zamanda şiddete karşı olmaları düşünülebilir. Bunun yanı sıra, öğretmenin ilkokulun temel eğitim olmasının ve toplumu şekillendirmenin temeli olduğunun farkında olması ve bu bilinçle de kendisini sorumlu hissettiğini söylemek mümkün olacaktır. Ayrıca, lise öğretmeni de muhatap olduğu öğrencilerin yaş ve gelişim itibariyle ergenlik döneminde olmasından dolayı daha hassas davranılması gerektiği, bu kritik dönemde öğrenciyi anlayacak, ona olumlu rol model olacak olmanın gerekliliğini kavraması ve bu bilinçle hareket etmesinden dolayı da ortaokul öğretmenine göre daha fazla kişisel ve toplumsal sorumluluk hissettiklerini ve şiddete daha fazla karşı olduklarını söylemek mümkündür. İşbirliğine açı olma boyutuna ilişkin ilkokul öğretmeninin hitap ettiği öğretim kademesi gereğince her alanda bilgiye sahip olma zorunluluğu vardır. Alan geniş olunca da öğretmenlerin eksik, yetersiz kaldığı durumlar olabilmektedir. Bu durumlarda meslektaşlar arası işbirliğine daha çok başvurabilmektedirler. Bu durumun ilkokul kademesinde görev yapan öğretmenlerin lise ve ortaokul kademesinde görev yapan öğretmenlere göre işbirliğine daha açık olmaları üzerinde etkili olduğu düşünülebilir. Farklılıklara saygılı olma boyutuna ilişkin ise ilkokul öğretmenleri öğrencilerle birebir ilgilendikleri için öğrencileri daha yakından tanıma firsatı bulduklarını ve dolayısıyla farklılıkları daha iyi tespit ettiklerini söylemek yanlış olmayacaktır. İlkokul kademesinde görev yapan öğretmenlerin lise ve ortaokul kademesinde görev yapan öğretmenlere göre öğrencilerin bireysel farklılıklarına karşı farkındalıklarının bu farklılıklara karşı daha saygılı olmaları üzerinde etkili olduğu düşünülebilir.

Araştırma sonucunda, öğretmenlerin farklılıklara saygı duyma ve şiddete karşı olma mesleki değerlerine sahip olma düzeyleri mesleki deneyime göre anlamlı bir fark göstermezken; 16 yıl ve üzeri mesleki deneyime sahip olanların 1-5 ve 6-10 y1l mesleki deneyime sahip olanlara göre kendilerinin daha fazla kişisel ve toplumsal sorumluluk sahibi olduklarını ve işbirliğine daha açı olduklarını düşündükleri sonucuna ulaşılmıştır. Öğretmenlerle yapılan görüşmelerde ise öğretmenlerin tamamı mesleki deneyimi fazla olan öğretmenlerin mesleki deneyime daha az olan öğretmenlere göre kendilerini kişisel ve toplumsal anlamda daha az sorumlu hissettikleri, ayrica mesleki deneyimi fazla olan öğretmenlerin işbirliğine daha az açık olduklarını belirtmişlerdir. Bu sonuç nicel verilerle elde edilen sonuçlarla çelişmektedir. Alanyazında yapılan çalış- 
malar incelendiğinde; Yılmaz (2011) tarafından yapılan çalışmada öğretmenlerin "demokratik" değerlerde kıdeme göre herhangi bir farklılık görülmezken, "dayanışma" ve "özgürlük" boyutunda farklılaşma görüldüğü, bu farklılaşmanın da 21 ve üzeri mesleki kıdeme sahip öğretmenlerin lehine olduğu sonucuna ulaşılmıştır. Yurtseven (2003) tarafından yapılan bir başka çalışmada da öğretmenlerin değerlerinin "eşitlik" boyutunda kıdeme göre farklılaştığı sonucuna ulaşılmıştır. Erçetin (2000) tarafından yöneticilerin kişisel değerleri benimseme düzeyleri üzerine yapılan bir çalışmada, bu düzeylerin "yaratıcılık" ve "estetik" boyutlarında farklılaştığ 1 sonucu elde edilmiştir. Genç (2008) tarafindan yapılan çalışmada, ilköğretim okulu öğretmenlerinin demokratik değerlere göre farklılaştığı, bu farklılaşmanın da meslektaşlarına göre daha kıdemli olan öğretmenler lehine olduğu sonucu elde edilmiştir. Bu sonuç yapılan araştırmada elde edilen sonucu destekler niteliktedir. Öte yandan, Karadağ, Baloğlu ve Yalçınkayalar (2006) tarafından yapılan çalışmada öğretmenlerin mesleki değerleri ve Zoba (2000) tarafından yapılan çalışmada öğretmenlerin örgütsel değerlerinin kıdeme göre farklılaşmadığı sonuçları elde edilmiştir.

Bu sonuçlardan hareketle, öğretmenlerin farklılıklara saygı duyma ve şiddete karşı olma mesleki değerlerine sahip olma düzeylerinde mesleki deneyimin belirleyici bir yansıması olmazken; öğretmenlerin mesleki deneyimi arttıkça daha fazla kişisel ve toplumsal sorumluluk hissettiklerini ve işbirliğine daha açık olduklarını düşündüklerini söylemek mümkündür. Başka bir deyişle, meslektaşlarına göre daha az deneyimli olan öğretmenler kişisel ve mesleki olarak daha az sorumlu hissetmekte ya da daha az sorumluluk sahibi olmakta, meslektaşlarına göre işbirliğine daha açık olmaktadırlar. Öğretmenlerle yapılan görüşmeler göz önünde bulundurulduğunda mesleki deneyimi fazla olan öğretmenlerin daha az deneyime sahip olan öğretmenlere göre kişisel ve toplumsal olarak daha az sorumluluk sahibi olduklarını bunun yanında, daha az işbirliğine açık olduklarını söylemek mümkündür. Mesleki deneyimi fazla olan öğretmenlerin kendilerini her konuda tecrübeli görmeleri ve bu tecrübelerinin de onları her konuda yetkin kıldığı düşüncesine sahip olmalarından dolayı görüşmelerden bu doğrultuda bir sonuç çıktığını düşünmek doğru olacaktır. Bu araştırmada elde edilen sonuçlara dayanarak aşağıda bazı önerilere yer verilmiştir.

- Mesleğe yeni başlayan öğretmenlerin ve özelikle eğitim fakültesi mezunu olmayan öğretmenlerin kişisel ve toplumsal sorumluluk ile işbirliği açısından desteklenmesi gerektiği görülmektedir. Bu doğrultuda; mesleğe yeni başlayan öğretmenler ve eğitim fakültesi mezunu olmayan öğretmenler için 
sosyal sorumluluk projelerinin veya diğer paydaşlarla (öğretmen, veli, yönetici vb.) işbirliğini artıracak sosyal/kültürel/akademik etkinliklerin geliştirilmesi önerilebilir.

- Erkek öğretmenlerin şiddete karşı olma ve işbirliğine açık olma açısından proje, çalıştay, örnek olay vb. etkinliklerle desteklenmesi önerilebilir.

- Ortaokul kademesinde görev yapan öğretmenlerin kişisel ve toplumsal sorumluluk ile şiddete karşı olma açısından, lise ve ortaokul kademesinde görev yapan öğretmenlerin ise farklılıklara karşı saygılı olma ve işbirliğine açık olma açısından desteklenmesi gerektiği görülmektedir. Bu doğrultuda ortaöğretime öğretmen yetiştirme programlarında bu değerlerin kazandırılmasına yönelik seçmeli derslerin eklenmesi önerilebilir.

- Öğretmenlerin sahip olması gereken mesleki değerlerin belirlenmesinde öğretmenlik mesleği dışındaki bireylerden de fikir alınıp araştırmalar bu yönde genişletilerek mesleki değerlere farklı bakış açıları geliştirilebilir.

- Benzer çalışmalar öğretmen adayları, okul yöneticileri gibi farklı örneklem grupları üzerinde ve örneklem sayısı artırılarak yürütülebilir. Veriler çevrimiçi olarak değil, katılımcılara doğrudan ulaşılarak toplanılabilir. Ayrıca gözlem, günlük vb. ölçme araçlarıyla katılımcılarla daha uzun süreli etkileşim ve veri çeşitliliği sağlanarak benzer çalışmalar yapılabilir.

\section{Kaynakça}

Açıkgöz, Ü. K. (2003). Etkili ögrenme ve ögretme. İzmir: Eğitim Dünyası Yayınları. Akbaş, O. (2004). Türk milli eğitim sisteminin duyuşsal amaçlarının ilköğretim 2. kademedeki gerçekleşme derecesinin değerlendirilmesi (Yayımlanmamış doktora tezi). Gazi Üniversitesi, Eğitim Bilimleri Enstitüsü, Ankara.

Akın, U. ve Özdemir, M. (2009). Öğretmen adaylarının demokratik değerlerinin çeşitli değişkenler açısından incelenmesi: Eğitim bilimleri fakültesi örneği. Ankara University Journal of Faculty of Educational Sciences, 42(2), 183-198.

Akkiprik, G. B. (2007). Genel lise ögretmenlerine göre karakter eğitimi yoluyla ögrencilere kazandırllacak değerler: Çok boyutlu bir araştırma (Yayımlanmamış yüksek lisans tezi). Yeditepe Üniversitesi, Eğitim Bilimleri Enstitüsü, İstanbul.

Altınkurt, Y. ve Yılmaz, K. (2011). Öğretmen adaylarının öğretmenlerin mesleki etik dışı davranışlar ile ilgili görüşleri. Mehmet Akif Ersoy Üniversitesi Eğitim Fakültesi Dergisi, 1(22), 113-128. 
Altunay, E. ve Yalçınkaya, M. (2011). Öğretmen adaylarının bilgi toplumunda değerlere ilişkin görüşlerinin bazı değişkenler açısından incelenmesi. Kuram ve Uygulamada Ĕ̈itim Yönetimi Dergisi, 17(1), 5-28.

Aşkan, D. (2010). İlköğretim okulu yönetici ve öğretmenlerinin değer algılarının bazı değişkenlere göre incelenmesi (Yayınlanmamış yüksek lisans tezi). Ege Üniversitesi, Sosyal Bilimler Enstitüsü, İzmir.

Berkowitz, L. ve Daniels, L. R. (1963). Responsibility and dependency. The Journal of Abnormal and Social Psychology, 66(5), 429-436.

Bilge, F. (1997). Eğitim bilimleri öğrencilerinin sürekli kızgınlık düzeyleri ve kızgınlıklarını ifade biçimlerinin bazı değişkenler açısından incelenmesi. Hacettepe Üniversitesi Eğitim Fakültesi Dergisi, 13(13), 75-80.

Büyükkaragöz, S. S. ve Kesici, Ş. (1996). Öğretmenlerin hoşgörü ve demokratik tutumları. Kuramdan Uygulamaya Eğitim Yönetimi Dergisi, 3, 353-365.

Büyükkaragöz, S. Ş., Muşta, M. C. ve Pilten, Ö. (1998). Öğretmenlik mesleğine giriş. Konya: Mikro Basım.

Büyüköztürk, Ş. (2016). Sosyal bilimler için veri analizi el kitabı. Ankara: Pegem Akademi.

Chebat, J. C. (1986). Social responsibility, locus of control, and social class. The Journal of Social Psychology, 126(4), 559-561.

Creswell, J. W. (2014). Research design. Qualitative, quantitative, and mixed methods approaches. USA: Sage Publications Inc.

Çankaya, D. ve Seçkin, O. (2004). Demokratik değerlerinin benimsenmesi açısından ögretmen ve ögretmen adaylarının görüss ve tutumları. Uluslararası Demokrasi Eğitimi Sempozyumu, Çanakkale Onsekiz Mart Üniversitesi.

Çelik, F. ve Güven, M. (2011, Ekim). 5. Sinıf sosyal bilgiler programında sorumluluk, estetik ve doğal çevreye duyarlıllk değerlerinin kazandırllmasina ilişkin öğrenci ve öğretmen görüşleri. Değerler Eğitimi Sempozyumu: Sosyal ve Kuramsal Yönleriyle Değerler Eğitimi, Osmangazi Üniversitesi, Eğitim Fakültesi, Eskişehir.

Çelik, N. (2005). Okul-aile ilişskilerinde yaşanan sorunlar (Yayımlanmamış yüksek lisans tezi). Marmara Üniversitesi Eğitim Bilimleri Enstitüsü, İstanbul.

Çetin, Ş. (2004). Değiş̧en değerler ve eğitim. Milli Eğitim Dergisi, 161, 5-16.

Çoban, A. E., Karaman, N. G. ve Doğan, T. (2010). Öğretmen Adaylarının kültürel farklılıklara yönelik bakış açılarının çeşitli demografik değişkenlere göre incelenmesi. Abant İzzet Baysal Üniversitesi Dergisi, 10(1), 125-131.

Demirel, Ö. (2007). Kuramdan Uygulamaya Eğitimde Program Gelişstirme. Ankara, Pegem A Yayıncilık. 
Demirtaş, H. (2004). Demokratik sınıf yönetimi ve üniversite ögrencilerinin öğretim elemanlarının sınıf içi tutum ve davranışlarına ilişkin görüşleri. XIII. Ulusal Eğitim Bilimleri Kurultayı, İnönü Üniversitesi, Eğitim Fakültesi, Malatya.

Derman Sparks, L. (2010). Anti-bias curriculum: Tools for empowering young children (2th Ed). Washington D.C.: National Association for The Education of Young Children.

Deveci, H. ve Dal, S. (2007) Teachers view of values education in social studies curriculum. Fourtheenth International Conference on Learning, Johannesburg, South Africa.

Dilmaç, B. (2002). Insanca değgerler ĕgitimi. Ankara: Nobel Yayıncılık.

Dönmez, B. ve Cömert, M. (2007). İlköğretim okulu öğretmenlerinin değer sistemleri. Değerler Ĕ̆itimi Dergisi, 5(14), 29-59.

Ekmişoğlu, M. (2007). Erken çocukluk döneminde farklılıklara saygı eğitimi kavramı hakkında öğretmen görüşlerinin incelenmesi ve farklılıklara saygı ölçeği'nin geçerlik güvenirlik çalışması (Yayımlanmamış yüksek lisans tezi). Onsekiz Mart Sosyal Bilimler Enstitüsü, Çanakkale.

Erçetin, Ş. (2000). İlköğretim okulları hangi değerle yönetiliyor? Anadolu Üniversitesi Eğitim Fakültesi Dergisi, 10(1), 31-43.

Erdem, A.R. (2007). Eğitim fakültesi kültürünün önemli bir öğesi: Değerler (Pamukkale üniversitesi eğitim fakültesi örneği). Eurasian Journal of Educational Research (EJER), 7(26), 95-108.

Everard, B. (1995). Values as central to competent professional practice. In H. Busher \& R. Saran (Eds.), Managing teachers as professionals in schools. (pp. 131-150). Routhledge Publications.

Fyffe, L., Hay, I. ve Palmer, G. (2004). Issues and concerns in children's values education. (ed. Brendan Barlett, Fiona Bryer, Dick Roebuck) Educating: Weaving research into practice. Griffith University Publisher.

Genç, S. Z. (2008). An evaluation of teachers ‘views of primary school principals' practice of democratic values. Social Behavior and Personality, 36(4), 483-492.

Gözütok, D. F. (2008). Eğitim ve şiddet. Ankara: Gazi Kitabevi Yayınları.

Güven, E. (2012). Sınıf ögretmeni adaylarının farklılıklara saygı düzeyleri ile özerklik düzeyleri arasındaki ilişkinin incelenmesi (Yayımlanmamış yüksek lisans tezi). On Dokuz Mayıs Üniversitesi Sosyal Bilimler Enstitüsü, Samsun.

Halstead, J. M. ve Taylor, M. J. (2000). Learning and teaching about values: A review of recent research. Cambridge Journal of Education, 30(2), 169-202.

Hatunoğlu, Y. ve Hatunoğlu, A. (2005). Öğretmenlerin fiziksel cezalandırmaya ilişkin görüşleri. Atatürk Üniversitesi Sosyal Bilimler Dergisi, 6(2), 105-116. 
Hökelekli, H. (2010). Modern eğitimde yeni bir paradigma: Değerler eğitimi. Ĕ̆itime Bakış Dergisi, 6(18), 4-10.

Karadağ, E., Baloğlu, N. ve Yalçınkayalar, P. (2006). İlköğretim okulu yöneticilerinin öğretmenler tarafindan algılanan demokratik tutumları ile öğretmenlerin demokratik değerleri üzerine ilişkisel bir araştırma. Değerler Eğitimi Dergisi, 4(12), 65-82.

Karip, E. (2001). Sınıf yönetimi. Ankara: Pegem A Yayıncılık.

Kuran, K. (2002). Öğretmenlik mesleği (niteliği ve özellikleri). Edt. Adil Türkoğlu. Öğretmenlik mesleğine giriş. Ankara: Mikro Yayınları.

Kuş, D. (2009). İlkögrretim programlarının, örtük programın ve okul dışı etmenlerin değerleri kazandırma etkililiğinin 8. sinıf ilköğretim öğrencilerinin ve ögretmenlerinin görüşlerine göre incelenmesi (Yayımlanmamış yüksek lisans tezi). Yıldız Teknik Üniversitesi, Sosyal Bilimler Enstitüsü, İstanbul.

Mehmedoğlu, Y. ve Mehmedoğlu, A. U. (2006). Küreselleşme: Ahlâk ve değgerler. İstanbul: Litera Yayıncılık.

Miles, M. B. ve Huberman, A. M. (1994). Qualitative data analysis (2nd edition). Thousand Oaks, CA: Sage Publications.

Oğuz, A. (2011). Öğretmen adaylarının demokratik değerleri ile öğretme ve öğrenme anlayışları. Değgerler Ĕgitimi Dergisi, 9(22), 139-160.

Öğüdülmüş, S. (2006). Okullarda şiddet ve önlenmesi. Ed. Selahattin Gelbal, Okullarda şiddetin önlenmesi, mevcut uygulamalar ve sonuçları. Erişim adresi: https://www.ted.org.tr/wp-content/uploads/2019/04/Okullarda_Siddet.pdf

Özden, Y. (1997). Öğrenme ve ögretme. Ankara: Pegem A Yayıncılık.

Özensel, E. (2003). Sosyolojik bir olgu olarak değer. Değerler Ĕ̆itim Dergisi, 1(3), 217-240.

Patton, M. Q. (2002). Qualitative research \& evaluation methods. USA: Sage Publications, Inc.

Rokeach, M. (1973). The nature of human values. New York: The Free Press.

Sabatier, C. ve Willems, L. L. (2005). Transmission of family values and attachment: A french three-generation study. Applied Psychology: An International Review, 54(3), 378-395.

Sabuncuoğlu, Z., ve Tuz, M. (2003). Örgütsel psikoloji. Bursa: Furkan Ofset.

Sağnak, M. (2004). Örgütlerde değerler yönünden birey örgüt uyumu ve sonuçları. Kuram ve Uygulamada Ĕ̈itim Yönetimi Dergisi, 37(37), 72-95.

Sağnak, M. (2005). İlköğretim okullarında görevli yönetici ve öğretmenlerin örgütsel değerlere ilişkin algıları. Eğitim ve Bilim, 30(136), 31-38. 
Sarı, E. (2005). Öğretmen adaylarının değer tercihleri: Giresun eğitim fakültesi örneği. Değerler Ĕ̆itimi Dergisi, 3(10), 75-90.

Senemoğlu, N. (2010). Gelişim, ögrenme ve ögretim: Kuramdan uygulamaya (16. baskl). Ankara: Pegem Akademi Yayıncılık.

Sezgin, F. (2006). İlköğretim okulu öğretmenlerinin birey-örgüt değer uyumuna ilişkin algıları. Kuram ve Uygulamada Ĕ̆itim Yönetimi, 12(4), 557-583.

Şahin Frrat, N. (2010). Okul müdürü ve öğretmenlerin okul kültürü ile değer sistemlerine ilişkin algıları. Eğitim ve Bilim, 35(156), 71-83.

Şişman, M. (2002). Eğitimde mükemmellik arayışı etkili okullar. Ankara: Pegem Yayıncilık.

Telatar, S. (2012). Illköğretim okullarında görev yapan ögrretmenlerin demokratik tutumları ile kişilik özellikleri arasındaki ilişkinin incelenmesi: İstanbul ili Anadolu yakası örneği (Yayımlanmamış yüksek lisans tezi). Yeditepe Üniversitesi, Sosyal Bilimler Enstitüsü, İstanbul.

Tunca, N. (2012). Illköğretim öğretmenleri için mesleki değerler ölçeğinin geliştirilmesi ve ilköğretim ögretmenlerinin mesleki değerlerinin belirlenmesi (Yayımlanmamış doktora tezi). Anadolu Üniversitesi, Eğitim Bilimleri Enstitüsü, Eskişehir.

Tunca, N., ve Sağlam, M. (2013). İlköğretim öğretmenlerine yönelik mesleki değerler ölçeğinin geçerlik ve güvenirlik çalışması. Eğitim Bilimleri Araştırmaları Dergisi, 3(1), 139-164.

Türkoğlu, A. (1996). 99 soruda eğitim bilimine giriş. İzmir: Memleket Gazetecilik ve Matbaacilik.

Yalar, T. (2010). İlköğretim sosyal bilgiler programında değgerler ĕgitiminin mevcut durumunun belirlenmesi ve ögretmenlere yönelik bir program modülü geliştirme (Yayınlanmamış doktora tezi). Mersin Üniversitesi, Sosyal Bilimler Enstitüsü, Mersin.

Yapıcı, A. ve Zengin, Z. S. (2003). İlahiyat fakültesi öğrencilerinin değer tercih sıralaması üzerine psikolojik bir araştırma: Çukurova Üniversitesi İlahiyat Fakültesi örneği. Dĕgerler Eğitimi Dergisi, 1(4), 173-206.

Yazıcı, K. (2011). Sosyal Bilgiler Öğretmen Adaylarının Demokratik Değerlerinin Çeşitli Değişkenler Açısından İncelenmesi. Eğitim ve Bilim, 36(159), 165-178.

Yıldırım, A. ve Şimşek, H. (2013). Sosyal bilimlerde nitel araştırma yöntemleri. Ankara: Seçkin Yayıncılık.

Yılmaz, K. (2011). İlköğretim okulu öğretmenlerinin sınıf yönetimi tarzları ile demokratik değerlere ilişkin görüşleri arasındaki ilişki. Değerler Ĕgitimi Dergisi, 9(21), 147-170. 
Yöndem, Z. D. ve Bıçak, B. (2008). Öğretmen adaylarının öfke düzeyi ve öfke tarzları. Uluslararası Insan Bilimleri Dergisi, 5(2), 1-15.

Yurtseven, R. (2003). Özel ortaögretim kurumlarında çalışan öğret-menlerin demokratik tutumları (Yayımlanmamış yüksek lisans tezi). Çukurova Üniversitesi, Eğitim Bilimleri Enstitüsü, Adana.

Zoba, A. (2000). Illköğretim okullarında varolan örgütsel değerlerle ögretmenlerin sosyalleşmesi arasındaki iliş̧ki (Yayımlanmış yüksek lisans tezi). Ankara Üniversitesi, Eğitim Bilimleri Enstitüsü. 
Extended Abstract

\section{Determining Teachers Opinions about Professional Values}

İshak KOZİKOĞLU, Corresponding Author, Assistant Professor.

Yüzüncü Yil University, Faculty of Education.

Email: ishakkozikoglu@yyu.edu.tr.

ORCID: 0000-0003-3772-4179

Ömer BEKLER, Teacher.

Email: bekleromer@gmail.com

ORGID: 0000-0003-4728-1914

\section{Introduction}

In today's society, people have become alienated from each other and become more and more individualized (Mehmedoglu and Mehmedoglu, 2006). Although the most important reason behind this is seen as a rapidly developing science and technology, the fact that the basic ties that connect people have lost their effects and disappear is one of the most important reasons behind this situation. The weakening or even disappearance of these ties cause people to no longer care about each other, ignore each other and, most importantly, show intolerance to each other. This situation is the biggest problem in today's society. Nevertheless, this problem is of course a solvable one, and to reach a solution some questions that beg answers are as followes: "What are the basic qualities that make people human?, "What are our responsibilities to each other besides our individual responsibility?", "What is the moral dimension of what we do, or what we have experienced?" (Dilmaç, 2002). Furthermore, all these questions have reference to the term "values". 
Values are one of the most important factors that enable individuals to adapt and socialize in the society they live in. The individual begins to learn and adopt his/ her point of view, emotional orientation, tradition and culture of the society in which he/she lives in. This learning process starts in the family as every learning process(Çelik and Güven, 2011; Fyffe, Hay and Palmer, 2004; Halstead and Taylor, 2000; Sabatier and Willems, 2005), then this process continues through media, educational institutions and social environment (Çelik and Güven, 2011; Fyffe, Hay and Palmer, 2004; Halstead and Taylor, 2000). Although this learning process starts in the family and continues through the social environment and the media, the most important task in this regard falls on schools. Even though the school encompass components such as; curriculum, students, parents, yet, the the most basic component is the teacher. The teacher enables the planning and organization of the instruction as required by the program within the teaching-learning activity. In addition, effective classroom management is required to create a positive behavioral change in students and to create an effective socialization and communication environment. The teacher also tries to create a positive classroom climate by taking this into consideration (Karip, 2001). However, all of these tasks and teachers' roles are possible with ideal teacher qualifications and one of these qualifications is having professional values. Although the professional values that teachers need to have are handled in a very wide framework, values such as "respect for differences", "personal and social responsibility", "being against violence" and "being open to cooperation" are emphasized in the literature. In this study, the professional values of teachers are discussed in this framework.

\section{Aim and Importance of the Study}

The aim of this study is to determine the level of teachers' professional values and their opinions on these values. Therefore, this study is expected to provide more in-depth data about teachers' professional values, therefore it will contribute to the literature related to teachers' and their colleagues' behaviors concerning professional values. In addition, it is thought that the results of this study will shed light on the needs analysis studies related to values education in in-service training programs that will be prepared for teachers in order to reveal their professional values. 


\section{Method}

\section{Research Model}

In this study, exploratory sequential design was used from mixed methods. In this study, firstly, quantitative data were collected and then qualitative data were obtained. In this way, it is aimed to carry out a more comprehensive and valid with the data supporting each other. Since the integration of qualitative and quantitative data allows for a more in-depth analysis of research problems compared to studies using a single method (Creswell, 2014), the mixed method was preferred in this study.

\section{Study Group}

The study group consists of 541 teachers who work in different branches in different provinces of Turkey. In addition, 21 teachers were interviewed in order to obtain qualitative data. In the determination of the study group, easily accessible convenience sampling was used. In this method, the researcher works on the group that is easy to access, thus providing practicality and speed to the study (Yıldırım \& Şimşek, 2013).

\section{Data Collection Tools}

In order to collect data in this study, "Professional Values Scale" and semi-structured interview form were used.

5-point Likert-type scale, developed by Tunca and Sağlam (2013), consists of 24 items ranging from "Never reflects me " to "It reflects me very much". It consists of four sub-dimensions that are "'respect for differences ", "'personal and social responsibility", "being against violence" and "being open to cooperation". Cronbach Alpha internal consistency coefficients of the sub-dimensions of the scale were calculated as $.77, .78, .70$ and .72 , respectively. In this study, they were calculated as $.72, .79, .74$ and .85 , respectively. According to these values, it can be said that the data obtained from the scale is reliable (Büyüköztürk, 2016).

The interview form prepared by the researchers consists of eight questions. These questions were prepared based on the dimensions "'respect for differences", " personal and social responsibility", "being against violence" and "being 
open to cooperation". Care was taken to ensure that the interview questions were clear and understandable. The interview form was prepared according to the expert opinions.

\section{Data Analysis}

Descriptive statistics, $\mathrm{t}$ test, ANOVA and descriptive analysis were used to analyze the data obtained in the study.

In this study, arithmetic means and standard deviations of the scale scores for the professional values of teachers were calculated. These values were interpreted "1-1.79" as very low, "1.80-2.59" as low, "2.60-3.39" as medium, “3.40-4.19” as high and "4.20-5.00” as very high level (Büyüköztürk, 2016). The t-test was used to determine whether the teachers' professional values differed according to gender and the faculty graduated, and ANOVA was used to determine whether teachers' professional values differed according to school level and professional experience. Furthermore, descriptive analysis technique was used for the analysis of qualitative data.

\section{Results}

As a result of the study, it was concluded that teachers have a very high level of professional value of "respect for differences"; they have high level of professional values that are "personal and social responsibility", "being against violence" and "being open to cooperation". Similar results were reached in interviews with teachers. It was concluded that the level of teachers' respect for differences and personal and social responsibility values did not show a significant difference according to gender, whereas female teachers have higher levels of being against violence and being open to cooperation than men. Teachers' level of respect for differences and values of being against violence did not show a significant difference according to the faculty, school level and professional experience; however, it was concluded that faculty of education graduates, the teachers working in primary, high school level and those with professional experience of 16 years and beyond have higher level of personal and social responsibility and are more open to cooperation than those who have 1-5 and 6-10 years professional experience, graduates of other faculties, and who work in the secondary school level. 


\section{Discussion, Conclusion and Suggestions}

Based on this study results, while there is no decisive reflection in terms of the levels of teachers' professional values regarding respect for differences and being against violence; yet, as teachers' professional experience increases, they feel more personal and social responsibility and think that they are more open to cooperation. In other words, teachers who are less experienced than their colleagues feel less responsible or have less responsibility personally and professionally and are more open to cooperation than their colleagues. Considering the interviews with teachers, it is possible to say that teachers with more professional experience have less personal and social responsibility than teachers with less experience, but also they are less open to cooperation. It would be right to think that the teachers who have more professional experience see themselves as experienced in all subjects and that these experiences make them competent in all subjects. Based on the results obtained in this study, some suggestions are given below.

- It is seen that teachers who are new to the profession and especially teachers who are not graduates of education faculties should be supported in terms of personal/social responsibility and cooperation. In this regard; responsibility projects or social/cultural/academic activities to increase cooperation with other stakeholders (teachers, parents, school administrators, etc.) may be proposed for teachers who are new to the profession and teachers who are not graduates of education faculties.

- For male teachers, various activities should be organized such as projects, workshops, case studies, etc. in order to increase their professional values of being against violence and being open to cooperation.

- Different perspectives on professional values can be developed by taking ideas from individuals outside the teaching profession and expanding the study in this direction in determining the professional values that teachers should have.

- Similar studies can be conducted on different sample groups such as prospective teachers, school administrators. The data can be collected by accessing the participants directly, not online. In addition, similar studies can be conducted by using data collection tools such as observation, dairy, etc. providing the chance of longer interaction with the participants and data diversity. 